\title{
Future Changes in Atmospheric Conditions for the Seasonal Evolution of the Baiu as Revealed from Projected AGCM Experiments
}

\author{
Yasuko OKADA \\ Japan Agency for Marine-Earth Science and Technology, Yokohama, Japan \\ Tetsuya TAKEMI, Hirohiko ISHIKAWA \\ Disaster Prevention Research Institute, Kyoto University, Kyoto, Japan \\ Shoji KUSUNOKI, and Ryo MIZUTA \\ Meteorological Research Institute, Tsukuba, Japan \\ (Manuscript received 22 June 2016, in final form 5 April 2017)
}

\begin{abstract}
This study investigates future changes in atmospheric circulation during the Baiu in Japan using 20-km-mesh atmospheric general circulation model (AGCM) simulations for the present-day (1979-2003) and the future (2075-2099) climates under the Representative Concentration Pathways 8.5 scenario. The simulated future climates include the outputs obtained with one control sea surface temperature (SST) and three different SST patterns. The Baiu frontal zone, defined as the meridional gradient of equivalent potential temperature, gradually moves northward during June-July-August in the present-day climate. In the future climate simulations using the control SST, the Baiu frontal zone is projected to stay to the south of Japan in June. Thus, precipitation is projected to increase over this region, while decreasing in the western part of Japan. Future changes in precipitation and atmospheric circulations in June are consistent across all four SST patterns. However, precipitation and atmospheric circulation in July and August in the future climate simulation depends on the SST patterns as follows: in non-El Niño-like SST pattern, the Baiu terminates in late July, similar to that of the present-day climate; a result with an El Niño-like SST pattern shows that sufficient amount moisture is transported to the Japanese islands and leads in a delay of the Baiu termination until August; and in the SST pattern with strong warming in the western North Pacific (WNP), a sufficient amount of moisture is transported to the south of Japan from June until August. The difference in the SST pattern leads to a variation in sea-level pressure in the WNP and affects a variation of the Northern Pacific subtropical high around the Japanese islands in July and August.
\end{abstract}

Keywords precipitation; the Baiu; global warming

Corresponding author: Yasuko Okada, Yokohama Institute for Earth Sciences, 3173-25, Showa-machi, Kanazawa-ku, Yokohama, Kanagawa 236-0001, Japan

E-mail: y-okada@jamstec.go.jp

J-stage Advance Published Date: 26 April 2017

(C)2017, Meteorological Society of Japan

\section{Introduction}

The Asian summer monsoon (ASM) onsets over the Bay of Bengal (BOB; $\left.85-95^{\circ} \mathrm{E}\right)$, the South China Sea (SCS; $\left.110-120^{\circ} \mathrm{E}\right)$, and the Indochina Peninsula $\left(90-110^{\circ} \mathrm{E}\right)$ in the middle of May (referred to as the first transition; Lau et al. 1998). It gradually extends to the adjacent regions (Matsumoto 1997; Wang and LinHo 2002; Ueda et al. 2009). In South Asia, the Indian summer monsoon begins in early June and 
matures in mid-June. In association with this behavior, East Asia experiences a rainy season from May to July that is called "the Meiyu" in China, "the Baiu" in Japan, and "the Changma" in Korea. The monsoonal southwesterly winds transport a sufficient amount of moisture to these mid-latitude regions. The Baiu frontal zone in the Japanese islands continues to move northward during June and July and disengages from the Japanese islands in late July. The termination of the Baiu has generally been attributed to the northward movement of the upper-level jet stream. In addition, Ueda et al. (1995) showed that the convection jump (CJ) over the subtropical western North Pacific (WNP) around $20^{\circ} \mathrm{N}, 150^{\circ} \mathrm{E}$ in late July causes the termination of the Baiu season. The CJ is the phenomenon of convection over the WNP that abruptly expands northeastward in mid-July.

The Baiu frontal zone is characterized by a narrow, steady precipitation zone and thick, moist neutral layer (Ninomiya 1984). More specifically, this front, elongated in the west-east direction, is defined by a strong meridional gradient of equivalent potential temperature (Matsumoto et al. 1971; Ninomiya and Akiyama 1992). Sampe and Xie (2010) explained the formation process of the Baiu frontal zone from a perspective of large-scale temperature advection in the mid-troposphere. In summer, the mid-troposphere air around the Tibetan Plateau is warmed not only by land-surface heating but also by latent heating due to the monsoonal convection in the southern part of Asia (Kato 1989; Kodama 1993; Ose 1998). Warm air that is heated over the Tibetan Plateau is transported to the southeastern part of China by the westerlies that are dominant in the upper troposphere. This horizontal temperature advection of warm air in the upper layer, along with the presence of a sufficient amount of moisture in the lower layer, induces enhanced convection in the vicinity of Japan (Sampe and Xie 2010). Sampe and Xie (2010) also showed a good correlation between the band of warm-air advection at the 500$\mathrm{hPa}$ level and the frontal zone over the Japanese islands during the Baiu season. Okada and Yamazaki (2012) closely examined whether this correlation applies to the Baiu around the Okinawa region (referred to as the Okinawa Baiu; $23-28^{\circ} \mathrm{N}, 123-129^{\circ} \mathrm{E}$ ). In the pre-Baiu season (i.e., May), a jet stream is present in the south of the Tibetan Plateau; however, the westeast contrast of temperature is weak over the Okinawa region. Thus, the prevailing southerly winds and warm-air advection at the $500-\mathrm{hPa}$ level, due to an enhanced meridional temperature gradient, play a role in generating the temporal peak of precipitation in the pre-Baiu period in the Okinawa region. However, in June, warm-air advection at the 500-hPa level strengthens because of the strong west-east thermal contrast between the warmer Tibetan Plateau and the colder WNP. Large-scale meteorological characteristics thus change between May and June.

In recent years, many studies on future global warming have shown that the termination of the Baiu in the Japanese islands is projected to be delayed at the end of the 21st century based on the analyses of datasets from the Coupled Model Intercomparison Project Phase 3 (CMIP3; Meehl et al. 2007) climate models adopted by the Intergovernmental Panel on Climate Change (IPCC 2007). In the CMIP3, an El Niño-like future change in the tropical Pacific is simulated by most models (Yamaguchi and Noda 2006). Uchiyama and Kitoh (2004) suggested that the delay of the Baiu termination is caused by the largescale circulation response to future changes in the SST pattern. This is similar to an El Niño-like mean SST change under the A2 scenario of the Special Report on Emission Scenarios (SRES) experiment of the Meteorological Research Institute (MRI)-coupled general circulation model (CGCM2). Uchiyama and Kitoh (2004) also reported that the Baiu onset timing in the future does not change significantly from that in the present climate. However, Kawase et al. (2009) suggested that the amount of precipitation under global warming increases over the southern part of the Baiu rainband in June, using the pseudo global warming downscaling method. They showed that this increase in precipitation is caused by two factors: the northeastward moisture flux over the northwestern Pacific Ocean at the lower level and the increase in the southward cold-air advection at the upper level. Kusunoki et al. (2011) showed that the termination of the Baiu tends to be delayed until August using the MRI-atmospheric general circulation model, version 3.1 (AGCM3.1). Weak seasonal evolution of the jet stream during the Baiu season was considered to play a role in causing this delay (Hirahara et al. 2012). Hirahara et al. (2012), using the CMIP3 dataset, suggested that the westerly jet in the future climate is more strengthened to the south than that in the present-day climate during summer. They attributed this strengthening to weaker upward motion associated with the ASM, which was in turn caused by the stabilized stratification in the tropical atmosphere under global warming. This southward strengthening of the westerly jet in the future climate results in a peak latitude of mid-tropospheric thermal advection than in the present-day climate in late July, which then 
significantly increases precipitation in the western part of Japan (Hirahara et al. 2012; Inoue and Ueda 2012; Kanada et al. 2012).

Regarding the large-scale atmospheric circulation, Inoue and Ueda (2011) reported that the first transition over the Indochina Peninsula is projected to be delayed at the end of the 21st century under the SRES A1B scenario compared with the present-day climate. In general, this transition in the present-day climate takes place in response to the reversal of meridional thermal gradient in the upper troposphere between the Asian continent and the tropics. The first transition is concurrent with the acceleration of monsoonal westerlies in the lower troposphere, extending from the BOB through the WNP (Li and Yanai 1996). However, in the future climate, the temperature rise in the upper troposphere is projected to be larger over the equatorial Indian Ocean than over the Asian continent in May (Ueda et al. 2006; Inoue and Ueda 2011), weakening the ASM circulation. Similar weakening signal of the ASM circulation was found in most of CMIP3 model projections in June, July, and August (Kitoh et al. 1997; Ueda et al. 2006; Hirahara et al. 2012). In this way, the greater warming projected in the future climate over the Indian Ocean, compared with that over the Asian continent, weakens the ASM circulation because of the smaller temperature difference in the middle-to-upper troposphere between the ocean and the continent. On the other hand, the summer monsoon rainfall in the future climate is projected to increase significantly compared with that in the present-day climate. This increase in rainfall depends on an increase in the atmospheric moisture content resulting from the temperature rise in future warm environment.

Although the evolution of the Baiu and the precipitation characteristics in the Japanese main islands have been extensively studied as described above, the relation between the large-scale atmospheric circulation and precipitation in the Baiu frontal zone, especially under global warming, has not been fully investigated. We suggest that understanding future changes to atmospheric circulation is critical to accurately understand changes in Baiu rainfall under global warming. In this study, we examine the future changes in the atmospheric conditions for the seasonal evolution of the Baiu season using the outputs of the 20-km-mesh MRI-AGCM simulations (Mizuta et al. 2012). The AGCM outputs for the future climates include the results obtained with one control SST and those obtained with three different SST patterns (Mizuta et al. 2014).

\section{Data}

\subsection{Climate simulation data}

We used 20-km-mesh simulation data for the present-day climate and the future climates obtained with the super-high-resolution global climate model developed by MRI, i.e., MRI-AGCM3.2S (Mizuta et al. 2012). Details of the model and the experimental design can be found in Mizuta et al. (2012) and Mizuta et al. (2014). The simulations utilized a massflux type cumulus convection scheme developed by Yoshimura et al. (2015).

The present-day and the future climate simulations were integrated for the 25 -year periods during 1979-2003 and 2075-2099, respectively. Simulation for the present-day climate was performed by prescribing the observed SST. The future climate experiments were performed with the Representative Concentration Pathways (RCP) 8.5 scenario adopted by the IPCC (2013) for global warming conditions. Four different spatial patterns of SST changes were applied to project the future climate: one with the mean SST changes averaged over the results from the 28 models participated in the Coupled Model Intercomparison Project Phase 5 (CMIP5) project and the three patterns of SST changes obtained from a cluster analysis of annual-mean tropical SST change patterns among the CMIP5 results (Mizuta et al. 2014). According to Mizuta et al. (2014), the characteristics of the three SST pattern are as follows: Cluster 1 shows smaller warming in the eastern tropical Pacific and larger warming in the Southern Hemisphere; Cluster 2 is similar to the observed pattern associated with an El Niño phase, consistent with the CMIP3 result that projects an El Niño-like response (Yamaguchi and Noda 2006); and Cluster 3 has the largest warming in the WNP among all the clusters.

In this study, the simulations are referred to as follows: the present-day climate simulation with the observed SST is referred to as $\mathrm{P} \_\mathrm{OB}$; the future climate simulation with the ensemble-mean SST is referred to as $\mathrm{F} \_\mathrm{C} 0$; and the future climate simulation with Cluster-1 SST, Cluster-2 SST, and Cluster-3 SST are referred to as $\mathrm{F}_{-} \mathrm{C} 1, \mathrm{~F}_{-} \mathrm{C} 2$, and $\mathrm{F} \_\mathrm{C} 3$, respectively. The first character indicates the period: the present-day climate $(\mathrm{P})$ and the future climate $(\mathrm{F})$. The third and fourth characters indicate the SST setting.

We used hourly data from the MRI-AGCM3.2S outputs with $20-\mathrm{km}$ resolution for precipitation, and six-hourly data at $1.25^{\circ}$ resolution for other meteorological variables. The three-dimensional meteorological datasets are coarser than those with $20-\mathrm{km}$ 
resolution, unlike datasets for the ground surface. Daily values are computed from the hourly data. The 25 -year mean values are computed for each day of the year to construct climatological values.

\subsection{Observation and reanalysis data}

To verify the climatology in the present-day climate simulation, we use meteorological data from the Japanese 55-year Reanalysis (JRA-55) (Kobayashi et al. 2015) and two observed precipitation datasets produced by the Asian Precipitation Highly-Resolved Observational Data Integration Toward Evaluation of the Water Resources (APHRODITE) project (Yatagai et al. 2012) and the Global Precipitation Climatology Project (GPCP_1DD; Huffman et al. 2001).

Although the JRA-55 dataset covers the years since 1958 , we select the same period as used for the simulated present-day climate by the MRI-AGCM3.2S. This dataset has a temporal resolution of six hours and a spatial resolution of $1.25^{\circ}$, the same resolution as the MRI-AGCM3.2S. The JRA-55 has been extensively improved since the Japanese 25-year Reanalysis (JRA-25) (Takahashi et al. 2006; Onogi et al. 2007; Watarai and Tanaka 2007).

The APHRODITE dataset has a horizontal resolution of $0.25^{\circ}$ and provides daily precipitation data over the terrestrial area for the Asian monsoon (Yatagai et al. 2012). This dataset covers the period since 1951, and we also select the same period as used in the present-day climate simulation.

The GPCP_1DD has a $1^{\circ}$ resolution; however, it only includes data since 1997. Therefore, we use data for the 12 years ending in 2008 for the comparison with the present-day climate. The GPCP_1DD combines a variety of satellite data and ground-based observational data. The accuracy of this dataset was evaluated by Huffman et al. (2001). They demonstrated that the precipitation in this dataset is slightly underestimated when compared with rain-gauge observations because the effects of terrain height are not considered in the GPCP_1DD. We include this dataset because it has the advantage of estimating precipitation not only over land but also over the ocean, unlike the APHRODITE dataset.

\section{Results}

\subsection{Monthly mean precipitation and future changes}

Generally, the Baiu frontal zone rapidly moves northward from May to June in Southeast Asia, and this northward shift leads to quasi-stationary precipitation and the onset of the Meiyu-Baiu season over a broad region in East Asia, from the southern part of
China to Japan (Kato 1985; Tanaka 1992). The Baiu frontal zone continues to move northward during June and July and disengages from the Japanese islands in late July. Figure 1 shows the distribution of monthly mean precipitation from June to August in the observations and in the present-day climate simulations. The observations indicate that in June the area with precipitation greater than $14 \mathrm{~mm}$ day ${ }^{-1}$ extends to the southern part of the Kyushu region $\left(129-132^{\circ} \mathrm{E}\right)$ and the Pacific Ocean side of Japan (Figs.1a, d). In July, this area gradually moves northward along with the Baiu frontal zone (Figs. 1b, e). The APHRODITE shows strong precipitation in the Kyushu region and in the Korean Peninsula in July (Fig. 1b). This increase in precipitation in the Korean Peninsula is concurrent with the Changma onset (Choi et al. 2012). The rainfall from the GPCP_1DD is smaller than that of the APHRODITE (Fig. 1e). The precipitation in August extends to the Pacific Ocean side of Japan as shown by the APHRODITE (Fig. 1c), and the precipitation increases from July to August in the Korean Peninsula as shown by the GPCP_1DD (Fig. 1f). The simulation indicates that in June, the precipitation is largest in the Kyushu region and the Pacific Ocean side of Japan among the Japanese terrestrial areas, which is consistent with observations (Fig. 1g). In July and August, the precipitation increases in the coastal areas and in the inland part of the Japanese islands, as well as in the Korean Peninsula (Figs. 1h, i). The simulation (Figs. 1g-i) generally reproduces the observed features well (Figs. 1d-f). This result is consistent with the study by Kusunoki (2016) who reported the advantage of the MRI-AGCM3.2S model over the CMIP5 atmospheric models. Kusunoki (2016) showed that the reproducibility of the MRI-AGCM3.2 models is greater than, or comparable with, that of the models that participated in CMIP5 for seasonal precipitation and seasonal evolution.

Figure 2 compares the distribution of monthly mean precipitation from June to August in the future climate simulations. The results from all the simulations demonstrate that in June the rainfall area covers not only the southern part of the Kyushu region but also areas further south $\left(\sim 30^{\circ} \mathrm{N}\right.$; Figs. $\left.2 \mathrm{a}, \mathrm{d}, \mathrm{g}, \mathrm{j}\right)$. All the simulations show that in July, the rainfall amounts in the Korean Peninsula and western part of the Kyushu region are large (Figs. 2b, e, h, k). In August, the rainfall area covers the western coastal area of the Korean Peninsula under all the SST patterns (Figs. 2c, f, i, l).

The future change in monthly mean precipitation between P_OB and F_C0 is shown in Fig. 3. In June, precipitation significantly increases around the WNP 

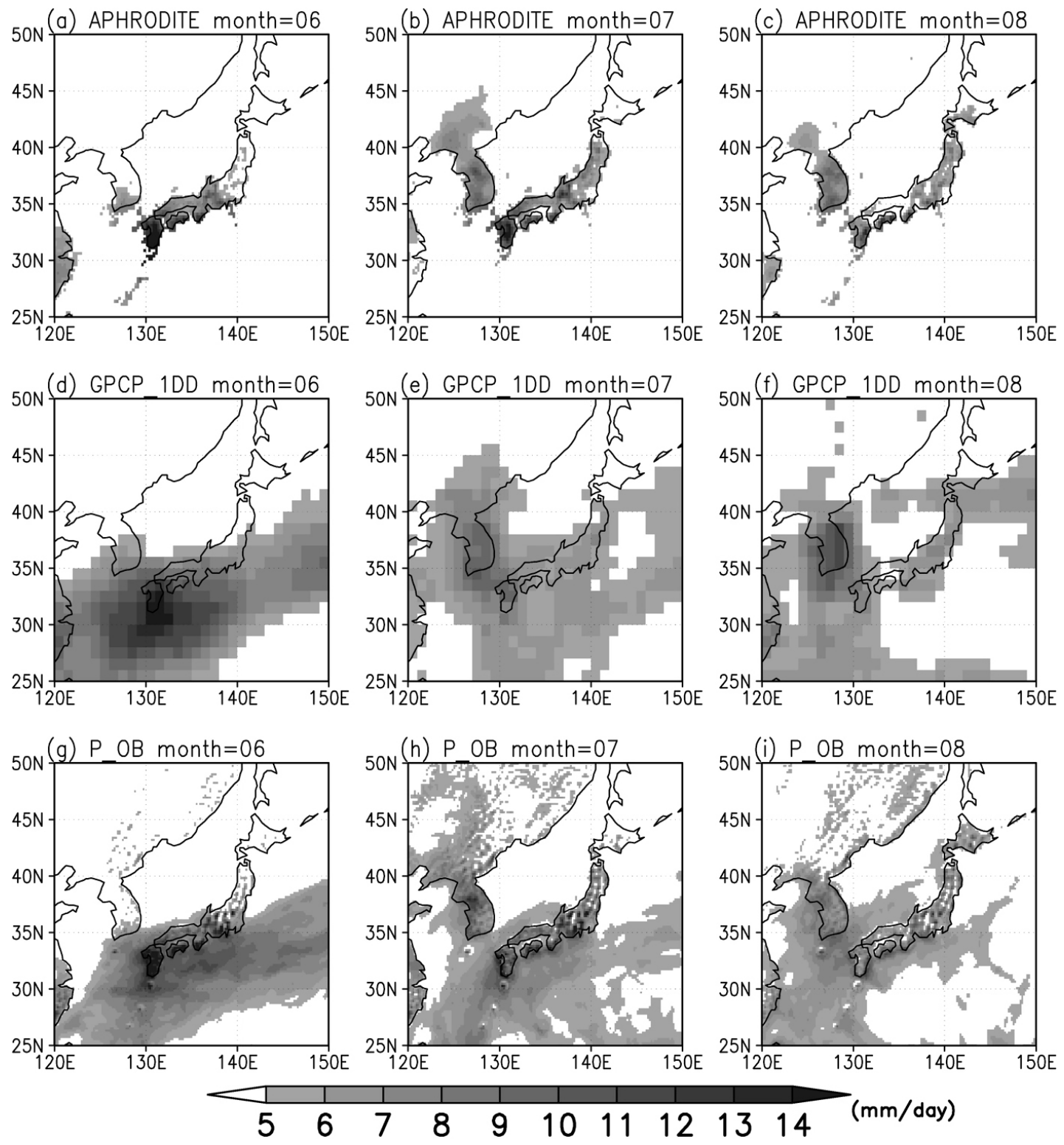

Fig. 1. Monthly mean precipitation (color shading; mm day ${ }^{-1}$ ) from June to August. (a)-(c) APHRODITE, (d)-(f) GPCP_1DD, and (g)-(i) the present-day climate simulation (P_OB). Columns indicate (left) June, (middle) July, and (right) August.

in the future climate and decreases significantly over the Japanese islands (Fig. 3a). In July, the precipitation increase extends to areas in the East China Sea, the Japanese islands, and China (Fig. 3b). In August, the precipitation in $\mathrm{F}_{-} \mathrm{C} 0$ significantly decreases in the WNP, the SCS, and most areas of the Japanese islands, while it increases over China (Fig. 3c). The precipitation change predicted for August differs from that seen in previous studies (Kitoh et al. 1997; Kusunoki et al. 2011; Hirahara et al. 2012), which showed that the termination of the Baiu season over the Japanese islands tends to be delayed until August. This inconsistency can be ascribed to the differences in the simulation settings employed in the previous studies and in the present study, specifically the differences in GCM, emission scenario, and the distribution 

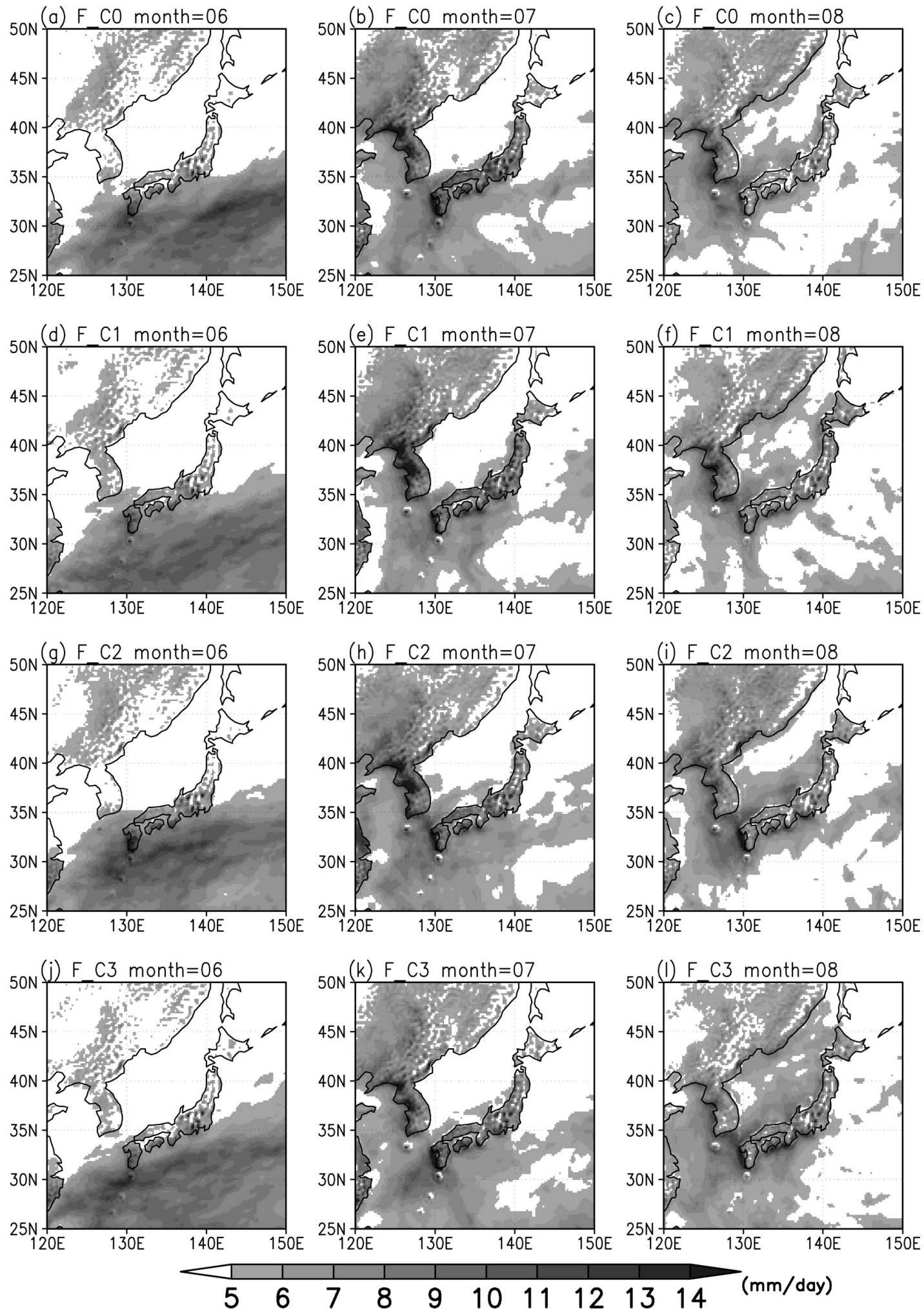

Fig. 2. Same as Fig. 1 but for the future climate simulations. (a)-(c) F_C0, (d)-(f) F_C1, (g)-(i) F_C2, and (j)-(1) F_C3. 

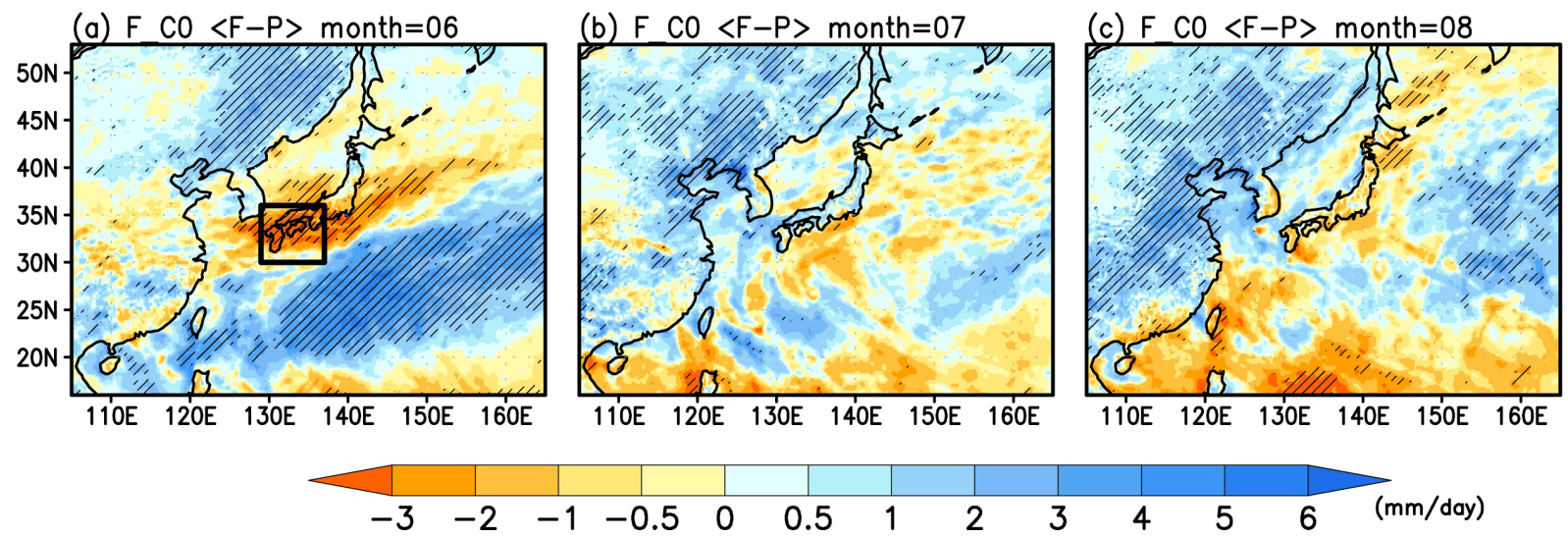

Fig. 3. Future change of precipitation $\left(\mathrm{mm} \mathrm{day}^{-1}\right)$ in $\mathrm{F}_{-} \mathrm{C} 0$ in (a) June, (b) July, and (c) August. Cold (warm) color indicates increase (decrease). The hatched areas show the $95 \%$ confidence level. The black box in (a) indicates the western part of Japan region $\left(30-36^{\circ} \mathrm{N}, 129-137^{\circ} \mathrm{E}\right)$.

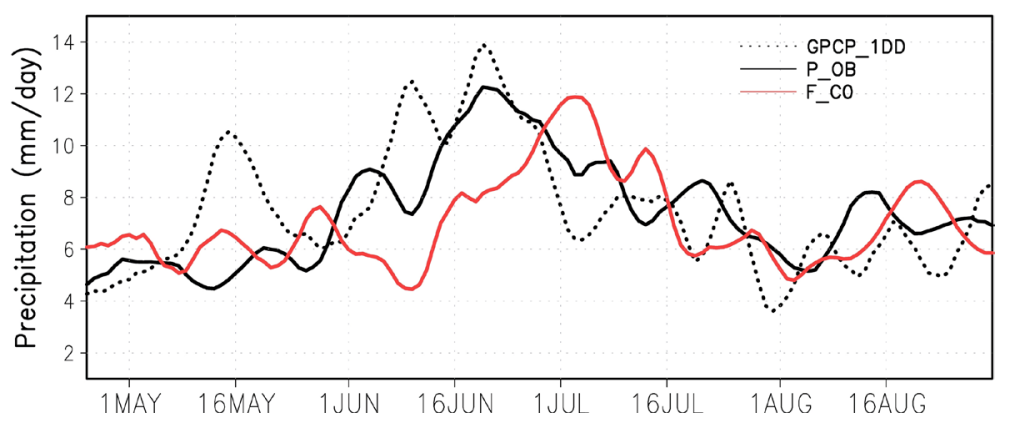

Fig. 4. Time series of precipitation $\left(\mathrm{mm} \mathrm{day}^{-1}\right)$ in the western part of Japan $\left(30-36^{\circ} \mathrm{N}, 129-137^{\circ} \mathrm{E}\right.$; Fig. 3a) from 25 April to 31 August based on 25-year climatologies from P_OB (black solid line), and F_C0 (red solid line). The dotted line indicates GPCP_1DD based on 10-yr averages. All lines are derived by twice applying a 5-day running mean to smooth the precipitation data.

of SST. Many CMIP3 models predict an El Niño-like responses (Yamaguchi and Noda 2006), and the termination of the Baiu is predicted to be delayed because of this SST response (Kitoh and Uchiyama 2006). The differences in atmospheric conditions among F_C1, F_C2, and F_C3 are explained in Section 3.3.

The temporal evolution of precipitation averaged over the western part of Japan from May to August in the observations, $\mathrm{P}_{-} \mathrm{OB}$, and $\mathrm{F} \_\mathrm{C} 0$ is presented in Fig. 4. We define the western part of Japan as the region from $30-36^{\circ} \mathrm{N}$ and $129-137^{\circ} \mathrm{E}$ (as indicated in Fig. $3 a)$. According to the GPCP_1DD, precipitation reaches the temporal peak of approximately $14 \mathrm{~mm}^{-}$day $^{-1}$ around mid-June. In P_OB, precipitation peaks at approximately $12 \mathrm{~mm}^{-}$day $^{-1}$ in mid-June, and this peak is consistent with the GPCP_1DD. Precipitation in the GPCP_1DD shows a temporal peak in mid-May, before the peak in mid-June, which corresponds to the Okinawa Baiu (Okada and Yamazaki 2012). However, the AGCM does not reproduce this peak (Fig. 4). The peak of precipitation in $\mathrm{F}_{-} \mathrm{C} 0$ is delayed by a half month compared with the P_OB results, though the amount of peak precipitation in F_C0 is comparable with that in $\mathrm{P}_{-} \mathrm{OB}$. Because of this delayed increase in precipitation in F_C0, the precipitation in June in $\mathrm{F}_{-}$ $\mathrm{C} 0$ decreases significantly in the western part of Japan (Figs. 3a, 4). Precipitation in F_C0 decreases after the peak in early-July and the Baiu season in this region terminates during late July and early August.

\subsection{Future changes to the Baiu frontal zone and moisture flux}

The Baiu frontal zone is defined as a sharp gradient in specific humidity and equivalent potential tem- 
perature in the lower troposphere (Matsumoto et al. 1971; Kato 1985; Ninomiya and Akiyama 1992). We examine the location of the Baiu frontal zone in this section. The Baiu frontal zone is defined here in terms of the meridional gradients of equivalent potential temperature $(\theta e)$ at the $925-\mathrm{hPa}$ level. The $\theta e$ value is approximated from the moist static energy divided by the specific heat at constant pressure. Figure 5 shows the time evolution of climatological meridional gradients in $\theta e$ at the $925-\mathrm{hPa}$ level averaged over the longitudinal range that contains the western part of Japan (as indicated in Fig. 3a), in the reanalysis (JRA55 ), and in the present-day climate simulation (i.e., $\mathrm{P}_{-}$ $\mathrm{OB})$. The sharp $\theta e$ gradient is located at approximately $30-35^{\circ} \mathrm{N}$ until mid-June, when it moves northward, in both JRA-55 and P_OB. A local minimum value of the north-south difference in $\theta e$ (less than approximately $-4 \mathrm{~K} \mathrm{deg}^{-1}$ ) indicates the position of the Baiu frontal zone.

Figure 6 shows the spatial distribution of monthly mean $\theta e$ values from June to August in the reanalysis (JRA-55) and in the simulations for the present-day (P OB) and the future climate with the control SST (F_C0). According to JRA-55, the negative $\theta e$ gradient areas less than $-4 \mathrm{~K} \mathrm{deg}^{-1}$ extend from the East China Sea to the Japanese islands in June (Fig. 6a). In July,

(a) JRA55

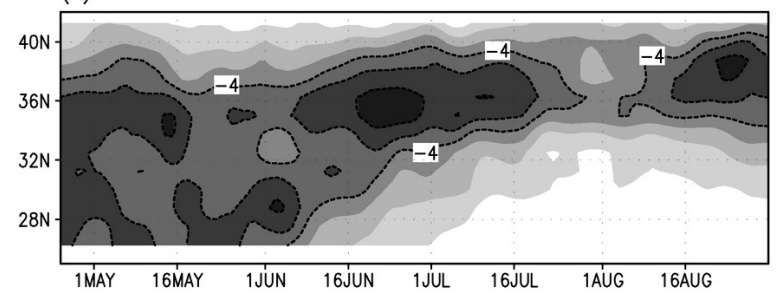

(b) $P_{-} \mathrm{OB}$

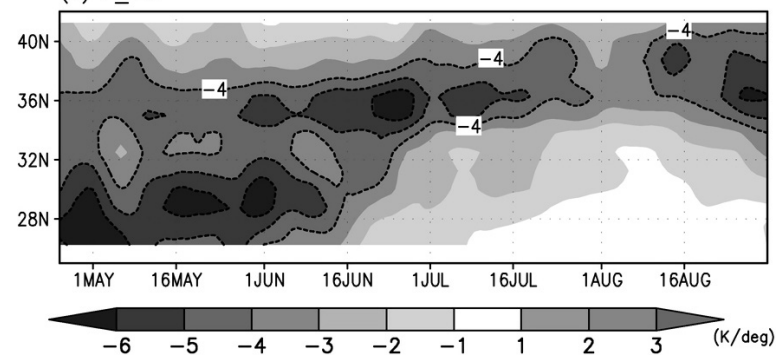

Fig. 5. Time-latitude plots of meridional gradients in equivalent potential temperature $(\mathrm{K})$ at the 925-hPa level over the longitudinal range 129$137^{\circ} \mathrm{E}$. All lines are derived by twice applying a 5-day running mean to smooth equivalent potential temperature. (a) JRA-55 and (b) P_OB. the negative gradient area along the Pacific coast of Japan disappears (Fig. 6b). According to Fig. 5, from late July to early August, the magnitude of the negative $\theta e$ gradient around $35-40^{\circ} \mathrm{N}$ becomes larger than $-3 \mathrm{~K} \mathrm{deg}^{-1}$, which indicates that the Baiu rainband has disengaged from the Japanese main islands (Figs. 4, 5). In addition, the strong $\theta e$ gradient areas in August extend to the northern part of Japan again because of the land surface heating on the Japanese islands (Fig. $6 c)$. The distribution of the Baiu frontal zone as shown in JRA-55 corresponds well with the spatial pattern of the observed precipitation (Figs. 1a-c, 6a-c). The $\theta e$ gradient in $\mathrm{P} \_\mathrm{OB}$ demonstrates that the Baiu frontal zone in the present-day climate simulation is able to reproduce the same northward shift as in JRA-55 throughout the summer (Figs. 6d-f). The northward shift reproduced in $\mathrm{P}_{-} \mathrm{OB}$ corresponds well with the observed distribution of precipitation in the Japanese main islands (Figs. 1, 6a-f). In addition, the equivalent potential temperature in $\mathrm{P}$ _OB is higher than in JRA-55 because of an effect of experimental setting (Mizuta et al. 2012; Kobayashi et al. 2015).

The value of $\theta e$ in the lower troposphere in $\mathrm{F} C 0$ rises by about $3-5 \%$ compared to that in $\mathrm{P}$ OB (Fig. $6)$. The region with a sharp negative gradient in $\theta e$ extends to the southern part of the Japanese islands in June. This extension is consistent with the increased precipitation to the south of Japan and the decreased precipitation in the western part of Japan simulated in F_C0 (compare Figs. 2a, 6g). This result indicates that the Baiu onset will be delayed in the future climate simulated by F_C0. Similar to the result of P_OB in

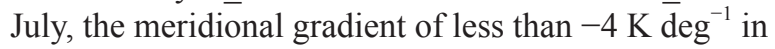
F_C0 is concentrated over the Sea of Japan as a result of the northward shift of the Baiu frontal zone (Figs. $6 e, h)$. In August in F_C0, the negative gradient over the Sea of Japan becomes weak (approximately -2 $\mathrm{K} \mathrm{deg}^{-1}$ ) (Fig. 6i).

In order to quantify the northward movement of the Baiu frontal zone, we define an index describing the seasonal evolution of this front. This index is defined as the difference between the area-averaged meridional gradient in $\theta e$ in the adjacent northern and southern regions which are defined in Fig. 6a. These areas are determined by the evolution of the Baiu rainband in the Japanese islands. Area $\mathrm{C}$ covers longitudinal range that includes the Okinawa region. The differences are computed by a subtracting meridional gradient in $\theta e$ in area $\mathrm{B}$ from that in area $\mathrm{C}$ (referred to as $\mathrm{CB}$ ) and by subtracting the meridional gradient in $\theta e$ in area $\mathrm{A}$ from that in area $\mathrm{B}$ (referred to as $\mathrm{BA}$ ). Figure 7 presents the seasonal evolution of $\mathrm{CB}$ and 

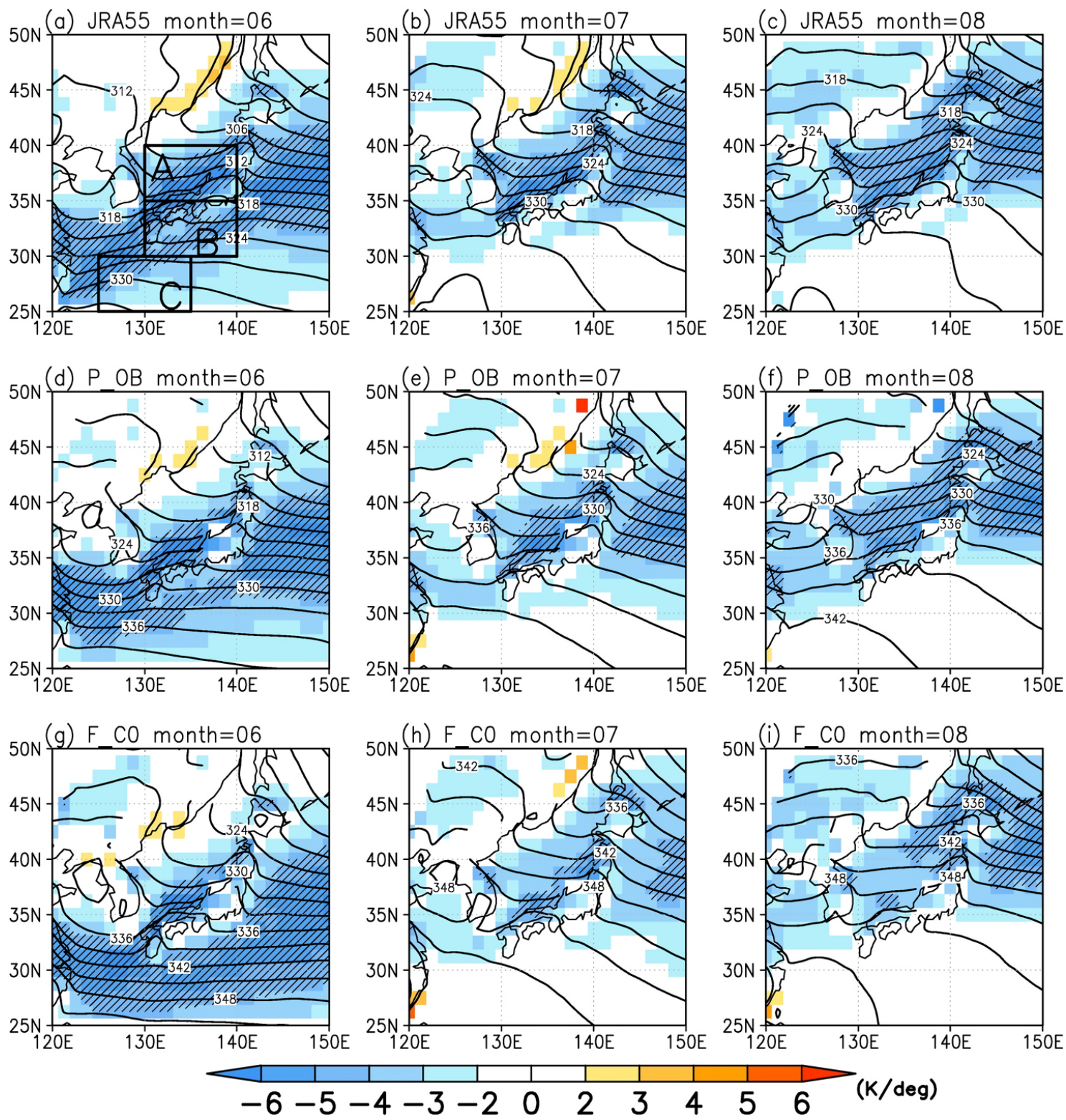

Fig. 6. Monthly mean equivalent potential temperature (contoured, $\theta e$; contour interval $3 \mathrm{~K}$ ) at the 925 -hPa level from June to August. (a)-(c) JRA-55, (d)-(f) P_OB, and (g)-(i) F_C0. Color shading indicates meridional gradient $\left(\mathrm{K} \mathrm{deg}^{-1}\right)$ and the hatched region indicates sharp gradient (less than $-4 \mathrm{~K} \mathrm{deg}^{-1}$ ). The black boxes in (a) indicate target regions of Fig. 7 (A: $35-40^{\circ} \mathrm{N}, 130-140^{\circ} \mathrm{E}, \mathrm{B}: 30-35^{\circ} \mathrm{N}, 130-140^{\circ} \mathrm{E}, \mathrm{C}: 25-30^{\circ} \mathrm{N}, 125-$ $\left.135^{\circ} \mathrm{E}\right)$.

BA from May to September as simulated in P_OB and $\mathrm{F} \_\mathrm{C} 0$. Before comparing the seasonal evolution between $\mathrm{P}_{-} \mathrm{OB}$ and $\mathrm{F} \_\mathrm{C} 0$, we compare features in $\mathrm{P}_{-}$ OB with those in JRA-55 for validation (Figs. 7a, b). It was found that there is a high correlation between P_OB and JRA-55 (the correlation coefficients for
$\mathrm{CB}$ and $\mathrm{BA}$ are above 0.80 ), which indicates that $\mathrm{P}$ OB captures the seasonal evolution of the Baiu frontal zone well.

Based on the validated performance of $\mathrm{P} \_\mathrm{OB}$, we now describe the changes in the seasonal evolution of the Baiu from the present-day to the future climate. 

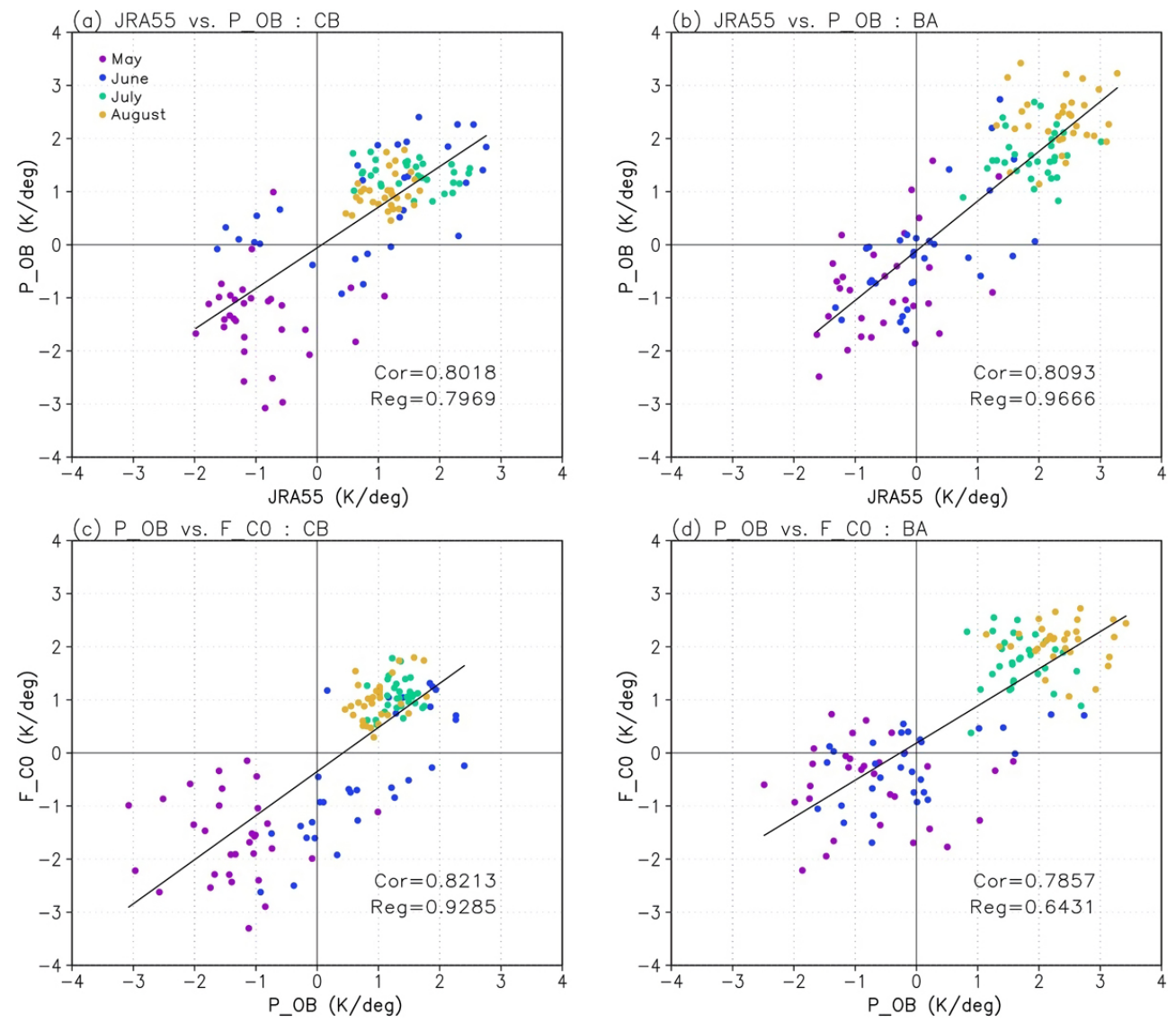

Fig. 7. Scatter diagram of the Baiu front index (unit; $\mathrm{K} \mathrm{deg}^{-1}$ ). Each point plots differences between meridional gradient of $\theta e$ in south area and that in north area. The definition of the regions is shown in Fig. 6a. (a) CB and (b) BA index show between JRA-55 and P_OB. (c) CB and (d) BA index show between P_OB and F_C0. Each color indicates as follows: (purple) May, (blue) June, (green) July, (yellow) August. This figure plots the daily data that is averaged of 25 years. The lower right of figures shows the correlation coefficient (Cor) and the regression coefficient (Reg).

The index $\mathrm{CB}$ indicates that the values in June are mostly negative in $\mathrm{F}_{-} \mathrm{C} 0$ and positive in $\mathrm{P} \_\mathrm{OB}$ (Fig. $7 \mathrm{c})$. This indicates that the Baiu frontal zone stays to the south of Japan in F_C0 (Figs. 2a, 6g). In other months, the signs of $\mathrm{CB}_{\overline{-}}$ in $\mathrm{P}_{-} \mathrm{OB}$ and $\mathrm{F}_{-} \mathrm{C} 0$ are mostly the same. The signs of the index $\mathrm{BA}$ in $\mathrm{P}_{-} \mathrm{OB}$ and $\mathrm{F}_{-} \mathrm{C} 0$ mostly agree with each other for all months examined here (Fig. 7d). BA in F_C0 does not become negative in July and August suggesting that the northward shift of the Baiu frontal zone in this region will not change significantly in the future climate (Figs. 6h, i, 7d). The northward shift demonstrated here differs from the CMIP3 results, which predicts that the Baiu frontal zone will stagnate over the Japanese islands until August in future (Uchiyama and Kitoh 2004; Kusunoki et al. 2011). The index BA in June in F_C0 is mostly negative and similar to that of $\mathrm{P} \_\mathrm{OB}$ (Figs. $6 \mathrm{~g}, 7 \mathrm{~d})$. This result is consistent with the meridional gradient in $\theta e$ in the Sea of Japan in June does not change significantly from the present-day to the future climate (Fig. 6g).

To explore large-scale atmospheric features surrounding the Baiu frontal zone, we examine the surface pressure fields in East Asia and the surrounding regions. Figure 8 shows the monthly mean sea level pressure (SLP) from June to August. The analysis fields in June (Fig. 8a) from JRA-55 indicate that the axis of the Northern Pacific subtropical high (NPSH) is located in the subtropics $\left(20-25^{\circ} \mathrm{N}\right)$. This high suppresses precipitation in the subtropics, and the Baiu frontal zone spreads to its northern side (Figs. 1a, d, 8a). The NPSH extends westward to the south of the 

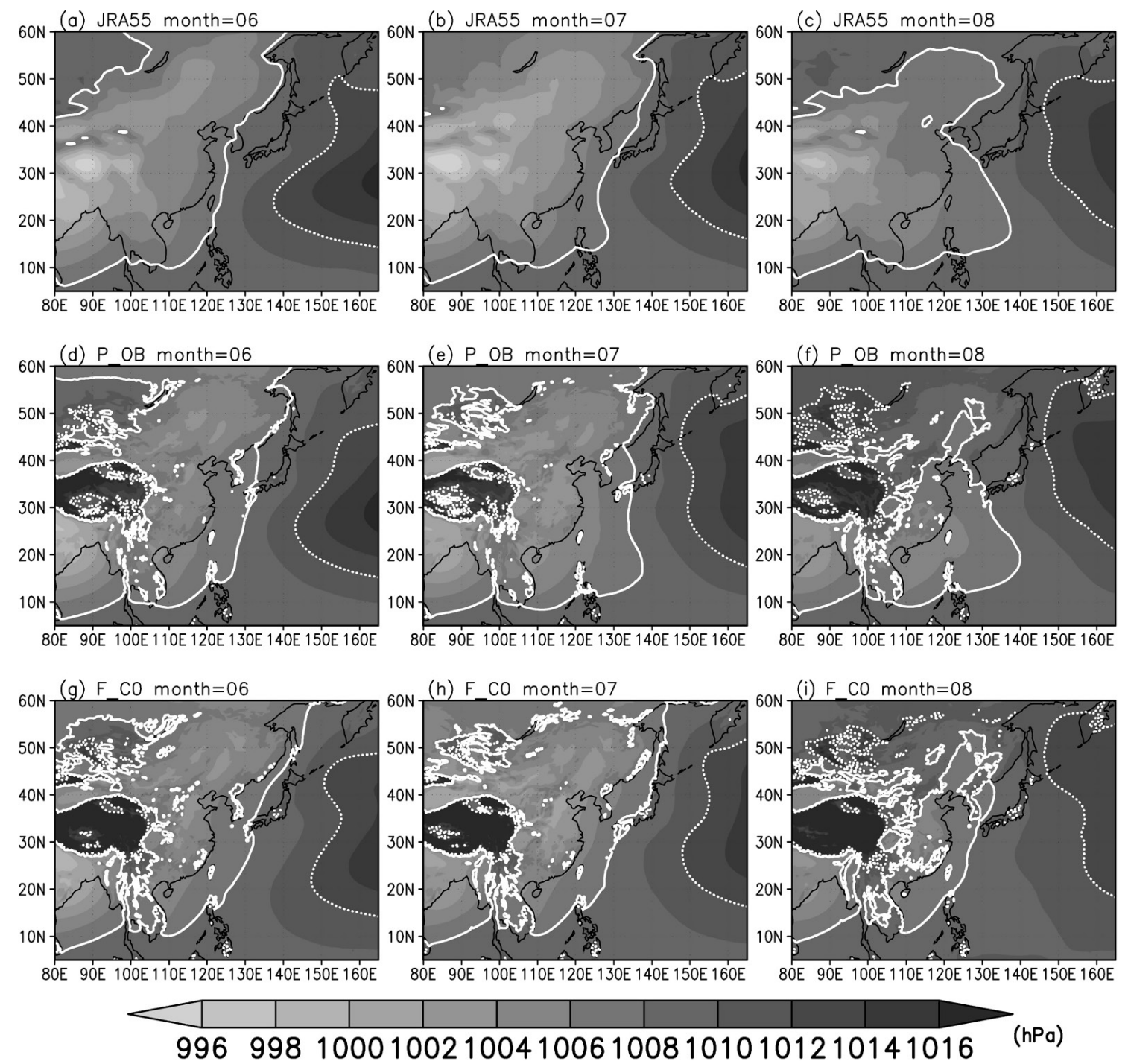

Fig. 8. Monthly mean sea level pressure (SLP; shading interval $2 \mathrm{hPa}$ ) from June to August. (a)-(c) JRA-55, (d)-(f) $\mathrm{P}$ OB, and (g)-(i) F C0. Columns indicate (left) June, (middle) July, and (right) August. The white solid line is $1008 \mathrm{hPa}$ and the dotted line is $1012 \mathrm{hPa}$.

Japanese islands in June (Fig. 8a), and this westward expansion persists in July (Fig. 8b). In August, the NPSH moves northward, and the western part of the NPSH covers part of the Japanese islands indicating that the Baiu frontal zone has disappeared (Fig. 8c). In contrast, a low-pressure region extends to the north of the Philippines in August. The seasonal evolution of these SLP features seems to be well reproduced in P_OB (compare Figs. $8 \mathrm{a}-\mathrm{c}$ and $\mathrm{d}-\mathrm{f}$ ), which indicates the validity of the present-day climate simulation by the MRI-AGCM2S.

The validated performance of the present-day climate simulation in representing large-scale atmospheric fields gives credence to the results from the future-climate simulations. The axis of the NPSH in June in F_C0 (Fig. 8g) is located further south (10$20^{\circ} \mathrm{N}$ ) than that in P_OB (Fig. 8a). This high gradually shifts northward (Figs. 8h, i), similar to what is seen in P_OB. As shown in Figs. 8h and 8i, in July and August a low-pressure region, which is found to the north of the Philippines in P_OB, does not extend eastward over the WNP and is limited to the South and the East China Sea. This low-pressure region is projected to be weak in Southeast Asia compared with 
P OB (Figs. 8d-f, $8 \mathrm{f}-\mathrm{i}$ ) and is weaker than the result of Kusunoki et al. (2006) analyzed under the A1B scenario.

The low-level transport of water vapor toward the frontal zone by the monsoonal wind is essential to the formation of Baiu precipitation (Ninomiya and Akiyama 1992; Tanaka 2007), and hence the moisture transport is examined here. Figure 9 shows the spatial distributions of moisture flux and column water-vapor content integrated between the 1000- and 200-hPa levels, to elucidate water vapor transport throughout this atmospheric layer from June to August in $\mathrm{P}_{-} \mathrm{OB}$. Although the moisture flux is integrated throughout the troposphere, water vapor is most abundant in the lower troposphere. The direction of the moisture flux therefore primarily reflects low-level moisture transport. Each figure shows 15-day (3 pentads) averages from June to August. In general, the convergence region of water vapor flux corresponds to the Baiu frontal zone (compare Figs. 1, 9). In June, the southwesterly moisture flux is dominant in the southern parts of China and Japan, with apparent convergence of the moisture flux in those areas (Figs. 9a, b). The convergence area is located in the northwestern edge of the NPSH (Fig. 8d) and gradually moves northward with seasonal evolution in July (Figs. 9c, d). In addition, the southwesterly moisture flux prevails in the western part of the Japanese islands and the convergence area extends to the Sea of Japan. During this period, the low pressure over the continent spreads eastward in response to the development of the East Asian summer monsoon (Fig. 8e). The NPSH moves northward in August and the convergence of moisture flux becomes weak over the Japanese main islands (Figs. 9e, f).

For the case of the future climate, the distributions of moisture flux and column water-vapor content from June to August in F_C0 are shown in Fig. 10. The southwesterly flux continues to prevail to the south of the subtropics during June (Figs. 10a, b). In comparison with $\mathrm{P}_{\mathrm{C}} \mathrm{OB}$, the area of moisture convergence is limited to the southern part of Japan and does not extend to the Sea of Japan side of the main islands. This result suggests that the Baiu frontal zone in June in F_C0 stagnates in the south of the Kyushu region (Figs. 9a, b, 10a, b). Generally, low-level water vapor transport into the Baiu frontal zone by the ASM winds is known to be essential for the formation of Baiu precipitation (Ninomiya and Akiyama 1992; Tanaka 2007). The ASM is driven by a large-scale thermal contrast between the Asian landmass and the neighboring oceans (Li and Yanai 1996; Ueda and Yasunari
1998). The onset of the ASM (the first transition) was projected to be delayed under global warming (Inoue and Ueda 2011). According to Inoue and Ueda (2011), this delay is caused by the delay of the reversal of the thermal contrast in the upper troposphere. We investigate the future change of temperature in the upper troposphere according to Ueda et al. (2006).

The future change (between $\mathrm{P} \_\mathrm{OB}$ and $\mathrm{F}_{-} \mathrm{C} 0$ ) of the thickness between the levels of $200 \mathrm{hPa}$ and 500 $\mathrm{hPa}$ in June is presented in Fig. 11. Figure 11 shows that the thickness between these levels in the tropics (more than $\sim 170 \mathrm{~m}$ ) is greater than that over the Asian continent (less than $110 \mathrm{~m}$ ), which suggests that the temperature rise in the tropics is larger. The increased temperature in the lower layer leads to an increase in the water vapor content with relative humidity being significantly unchanged due to water vapor feedback from $\mathrm{P}_{-} \mathrm{OB}$ to $\mathrm{F}_{-} \mathrm{C} 0$. This increase in water vapor content induces an obvious convergence of water vapor flux at lower latitude compared to P_OB (Figs. $10 \mathrm{a}, \mathrm{b})$. The increased water vapor content in the lower layer in addition to the delayed monsoon onset is predicted to result in increased precipitation to the south of the Japanese islands, shown in Figs. 3a, 10a, $10 \mathrm{~b}$, and 11 .

In July, the enhancement in southwesterly moisture flux from the East China Sea to the Japanese islands along the northwestern side of the NPSH ridge is greater in F_C0 (Figs. 10c, d) than in P_OB (Figs. $9 \mathrm{c}, \mathrm{d})$. Previous studies showed that ASM rainfall significantly increases under global warming, whereas ASM circulation is projected to become weaker (e.g., Ueda et al. 2006; Inoue and Ueda 2011). This increase in ASM rainfall is explained by results that show total moisture flux increases due to an increase in the atmospheric moisture content resulting from rising temperatures (Ueda et al. 2006). Results from the MRI-AGCM3.2S shows that the low-pressure region in Southeast Asia that spreads during monsoon onset is predicted to be weaker in $\mathrm{F}_{-} \mathrm{C} 0$ than in $\mathrm{P} \_\mathrm{OB}$ (Fig. 8). However, the northward moisture flux in F_CO prevails between the SCS and the Philippines from late-June to early-July, in contrast to that in P_OB (Figs. 9c, 10c). In addition, the southwesterly moisture flux transports a sufficient amount of moisture to the Japanese islands (Fig. 10c). This result suggests that the increase of atmospheric moisture content by global warming is an important contributor to Baiu rainfall predictions in F_C0.

Ueda et al. $(1995,2009)$ showed that an abrupt northward shift of the NPSH is associated with the CJ over the subtropical WNP $\left(10-25^{\circ} \mathrm{N}, 130-170^{\circ} \mathrm{E}\right)$ in 


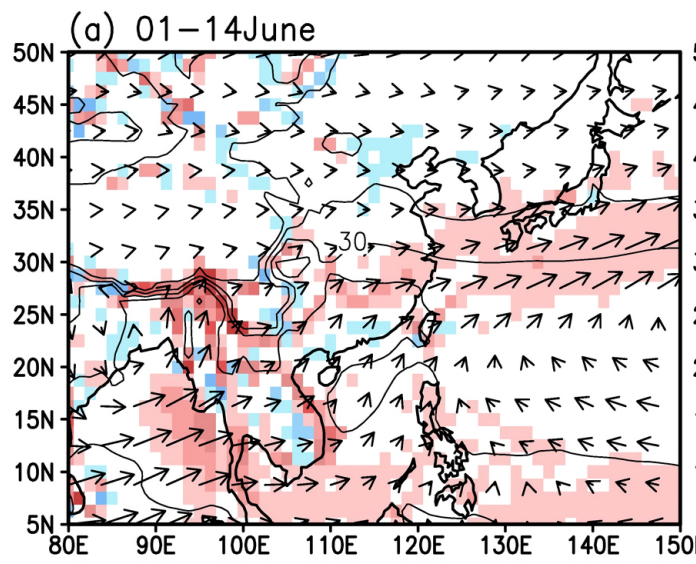

(b) 15-29June

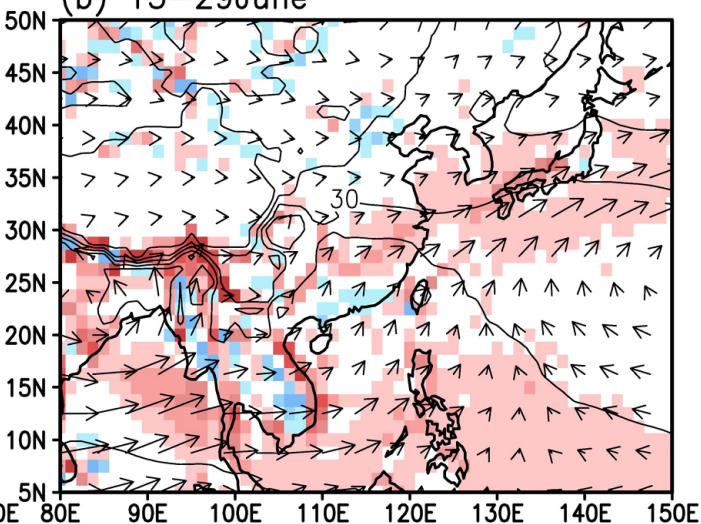

(c) 30June-14July

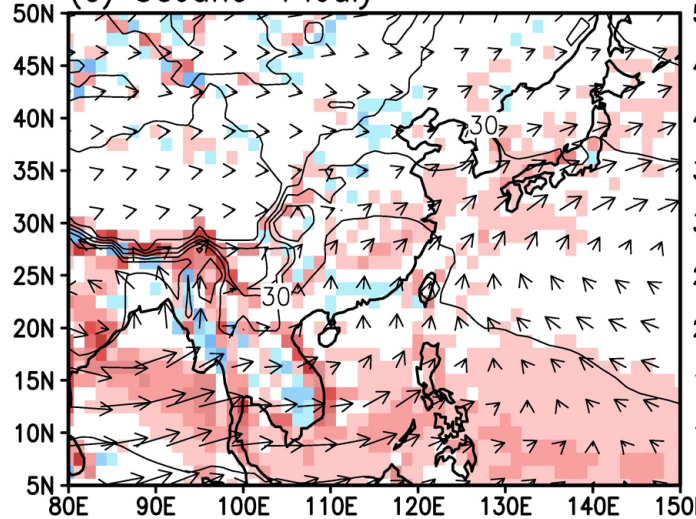

(d) 15-29July

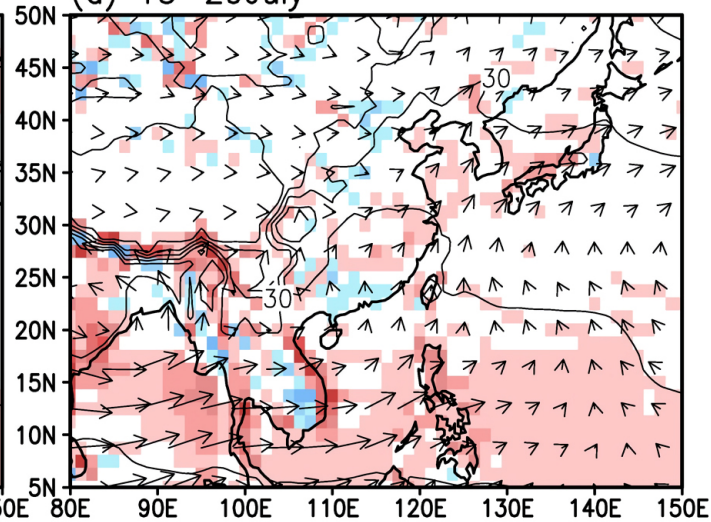

(e) 30July-13August

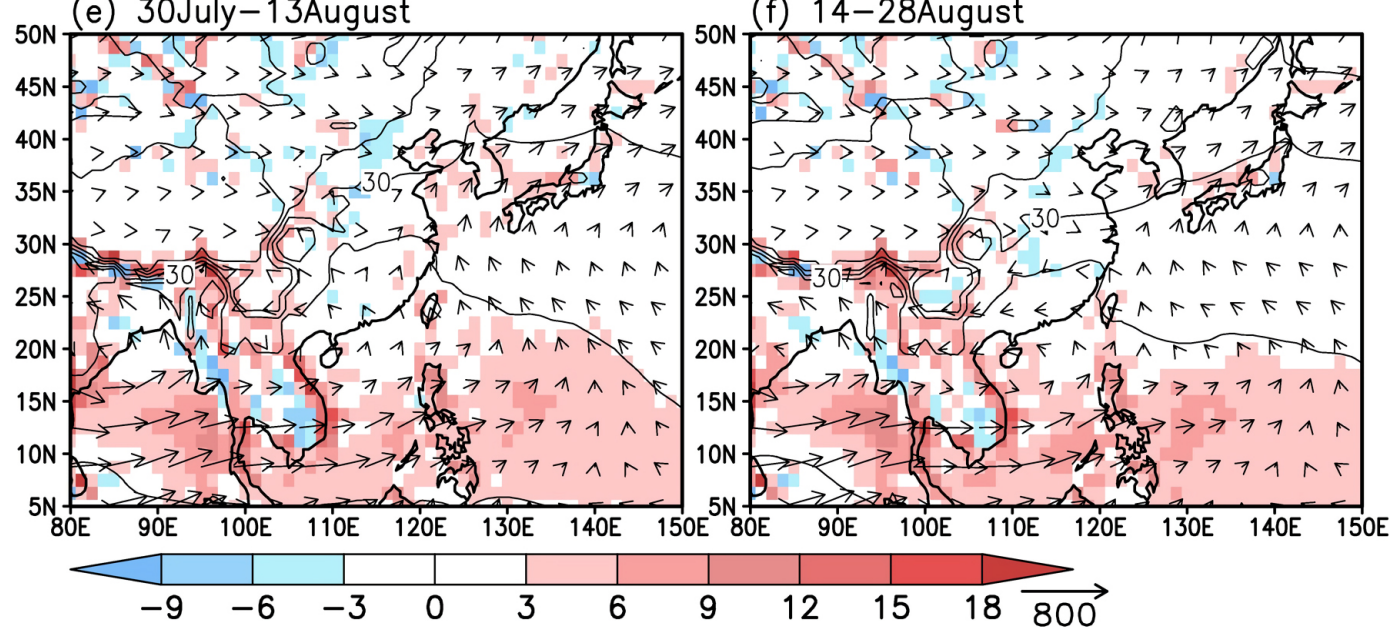

Fig. 9. Moisture flux (arrows; $\mathrm{kg} \mathrm{m}^{-1} \mathrm{day}^{-1}$ ), moisture flux convergence (shading; $\mathrm{kg} \mathrm{m}^{-2} \mathrm{day}^{-1}$ ), and column watervapor content (solid contours; $\mathrm{mm}$; contour interval $10 \mathrm{~mm}$ ) integrated between the $1000-\mathrm{hPa}$ and the $200-\mathrm{hPa}$ level in P_OB during summer. All distributions divide the June-August period into 15-day increments (3 pentads) except for (a) (14-day increments). (a) 1-14 June, (b) 15-29 June, (c) 30 June-14 July, (d) 15-29 July, (e) 30 July-13 August, (f) 14-28 August. 


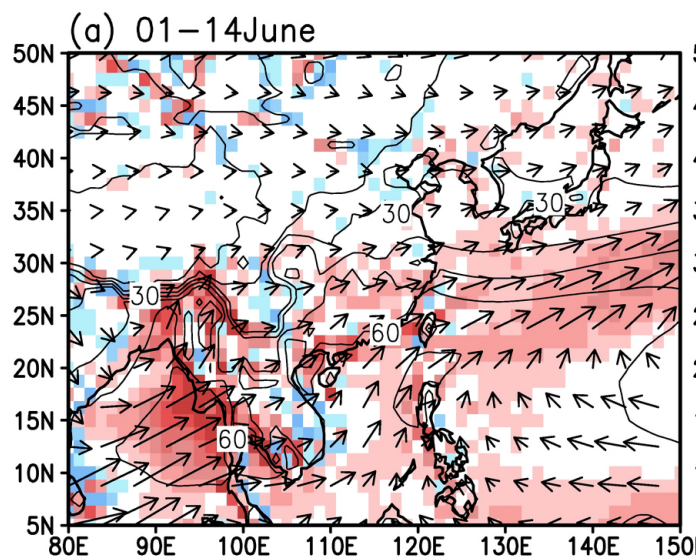

(b) 15-29June

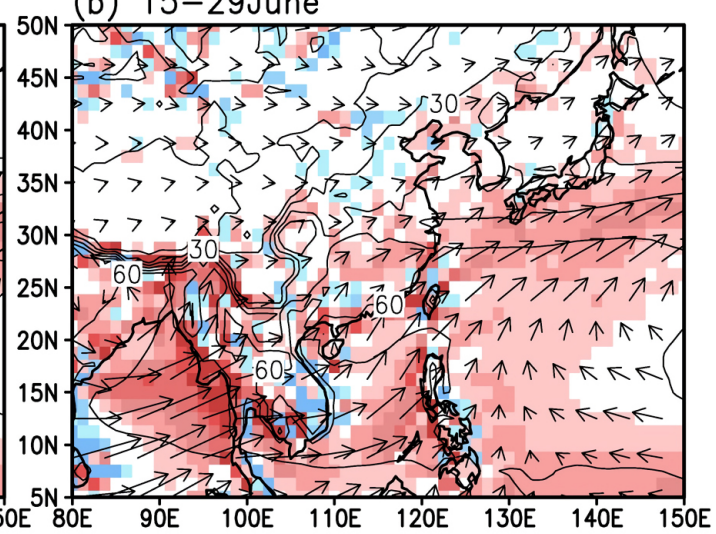

(c) 30June-14July

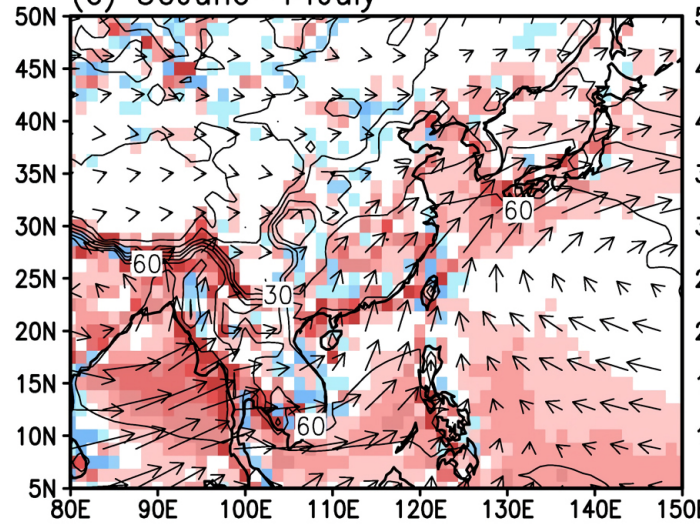

(d) 15-29July
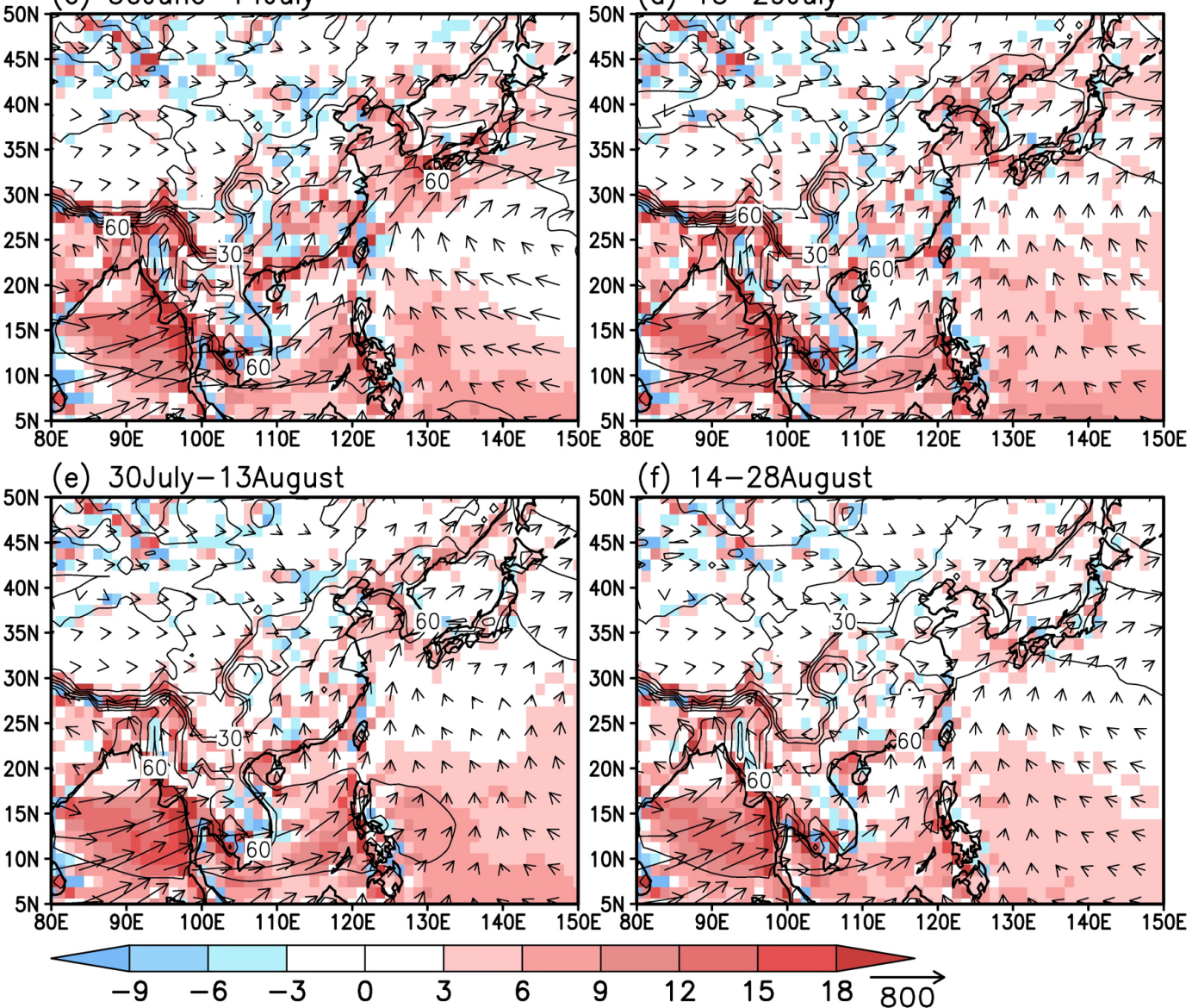

Fig. 10. Same as Fig. 9 but for F_C0.

late July. To highlight the difference before and after the $\mathrm{CJ}$, precipitation and $850-\mathrm{hPa}$ winds are averaged for six pentads before and after the CJ onset (Ueda et al. 2009). The difference of pentads $40-45$ to pentads $34-39$ is plotted in Fig. 12. According to Ueda et al. (2009), the CJ takes place in mid-July as a large cyclonic circulation develops around a region centered at around $15-25^{\circ} \mathrm{N}, 130-160^{\circ} \mathrm{E}$. In $\mathrm{F}$ C 0 , precipitation increases over this region, while precipitation decreases in the Japanese islands (Fig. 12a). Figure 


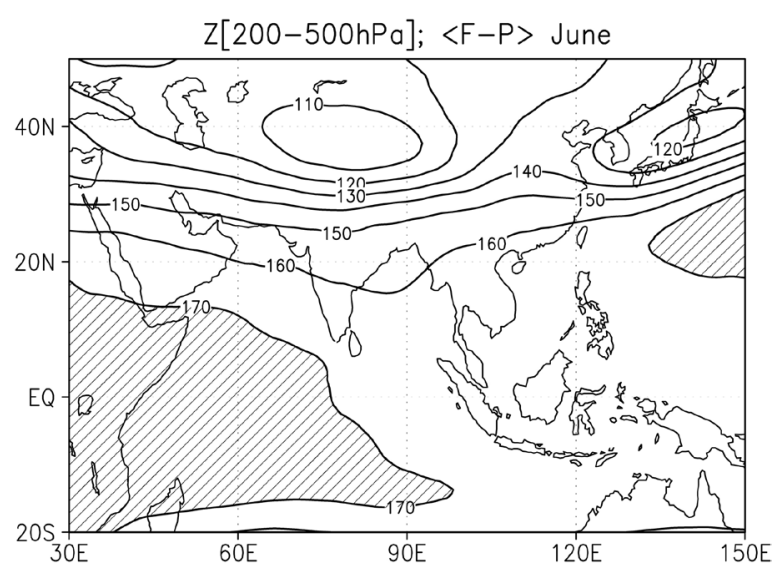

Fig. 11. Future change of $200-500 \mathrm{hPa}$ thickness (contour interval $10 \mathrm{~m}$ ) in June between $\mathrm{P}_{-} \mathrm{OB}$ and $\mathrm{F}_{-} \mathrm{C} 0$. The hatched region indicates area in excess of $170 \mathrm{~m}$.
12 also presents results from the AGCM experiments with other SST clusters (i.e., F_C1, F_C2, and F_C3). In $\mathrm{F}$ C1, the precipitation increases in the WNP in mid-July (Fig. 11b), while in $\mathrm{F} \mathrm{C2}$, active convection is stronger than other with SST patterns, and precipitation is more prevalent in the WNP (Fig. 12c). In F $\mathrm{C} 2$ and $\mathrm{F}$ C3, active convection over the WNP shifts slightly southward compared with F_C1 (Figs. 12b-d). This southward shift may affect the later termination of the Baiu in F_C2 and F_C3 compared with F_C1.

\subsection{Future changes in atmospheric conditions due to the difference in SST patterns}

In this section, we examine the response of precipitation and atmospheric circulation to the difference in different SST patterns. Figure 13 shows the future change of monthly mean precipitation in F_C1, F_C2, and F_C3. In June, the area of increased precipitation spreads to the south of Japan and the area of decreased precipitation spreads over the Japanese islands (Figs.
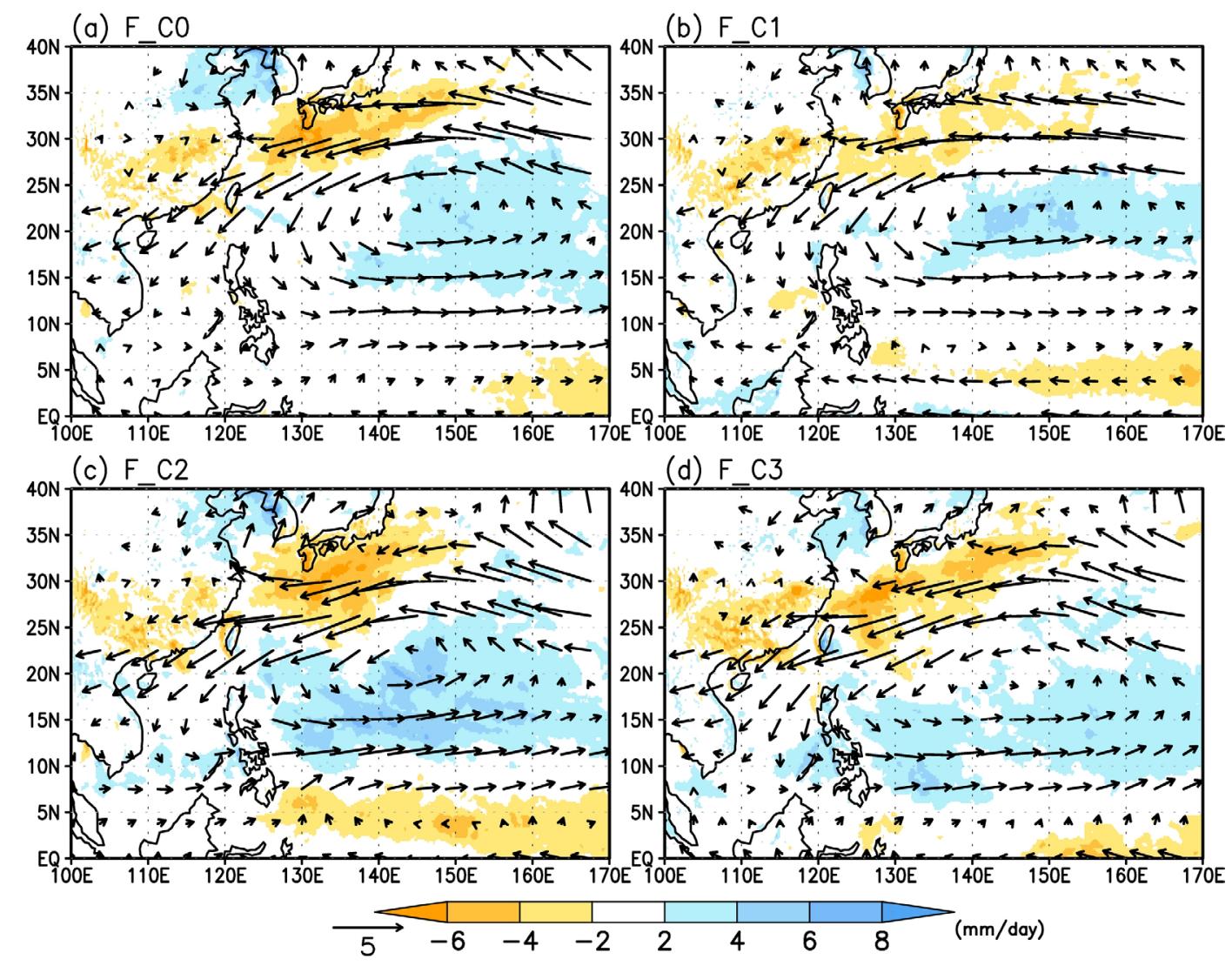

Fig. 12. Seasonal changes in precipitation $\left(\mathrm{mm} \mathrm{day}^{-1}\right)$ and $850-\mathrm{hPa}$ winds $\left(\mathrm{m} \mathrm{s}^{-1}\right)$ of the future climate $\left(\mathrm{mm} \mathrm{day}^{-1}\right)$ in mid-July (15July-13August minus 15June-14July). (a) F_C0, (b) F_C1, (c) F_C2, and (d) F_C3. 
(a) F_C1 $\langle\mathrm{F}-\mathrm{P}\rangle$ month $=06$

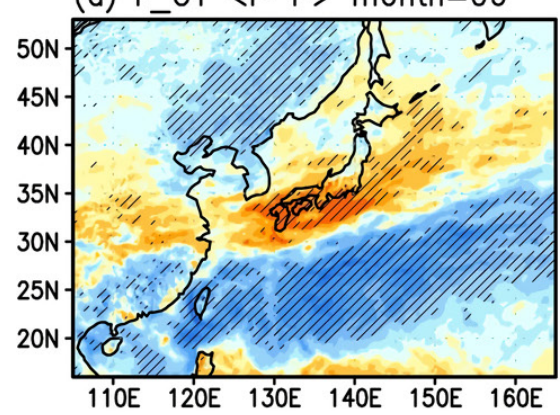

(d) F_C2 $\langle$ F-P $\rangle$ month $=06$

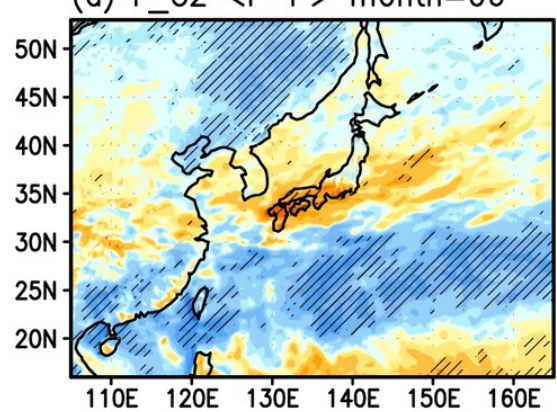

(g) F_C3 $\langle$ F-P $\rangle$ month $=06$

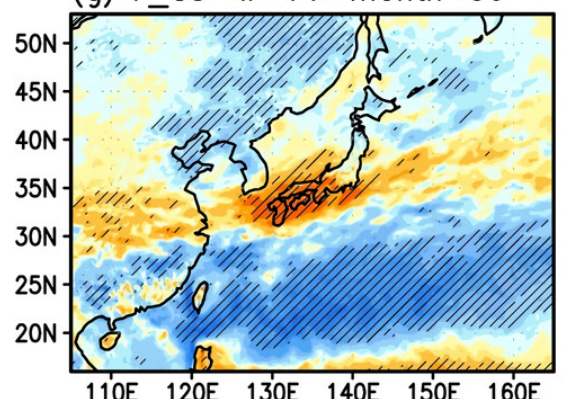

(b) F C1 $\langle\mathrm{F}-\mathrm{P}\rangle$ month $=07$

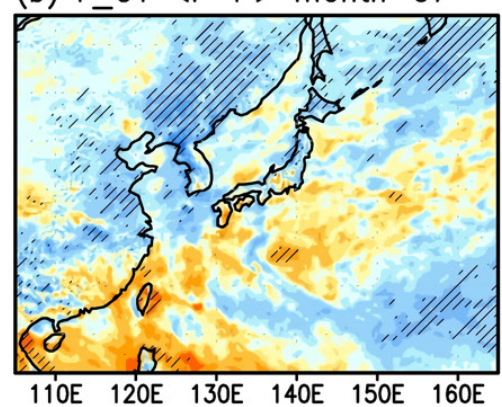

(e) F_C2 $\langle\mathrm{F}-\mathrm{P}\rangle$ month $=07$

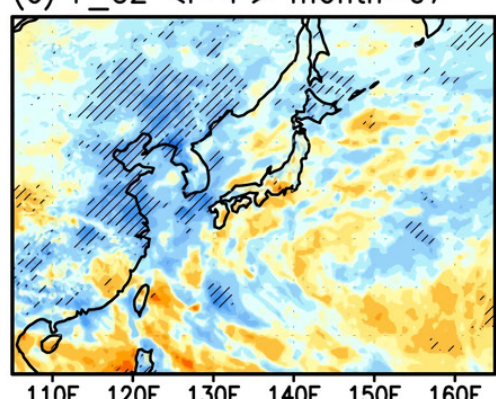

(h) F_C3 $\langle\mathrm{F}-\mathrm{P}\rangle$ month $=07$

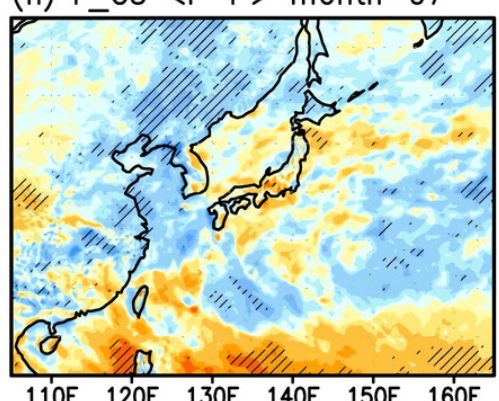

(c) $\mathrm{F}_{-} \mathrm{C} 1\langle\mathrm{~F}-\mathrm{P}\rangle$ month $=08$

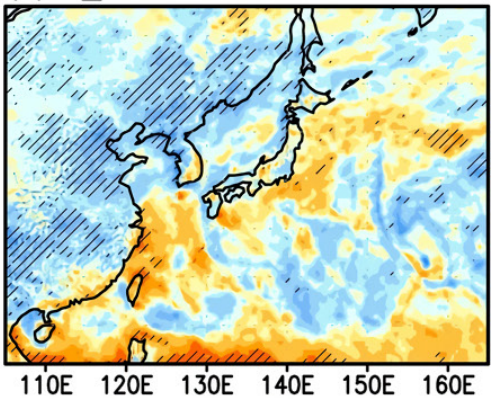

(f) $F_{-} C 2\langle F-P\rangle$ month $=08$

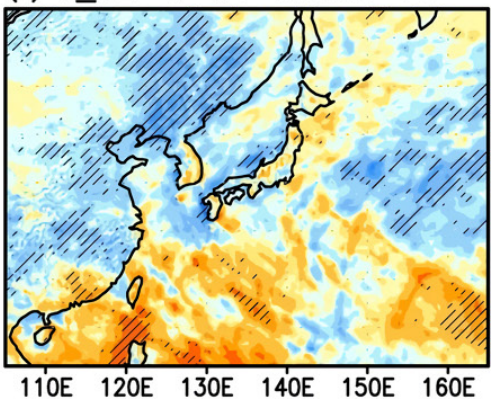

(i) $\mathrm{F}_{-} \mathrm{C} 3\langle\mathrm{~F}-\mathrm{P}\rangle$ month $=08$

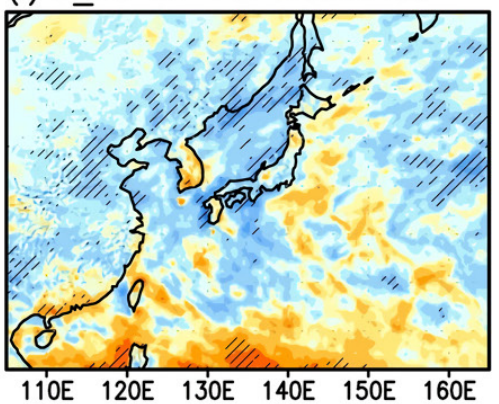

110E $120 \mathrm{E}$ 130E $140 \mathrm{E}$ 150E $160 \mathrm{E}$

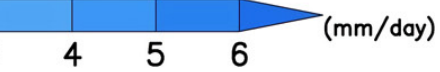

Fig. 13. Same as Fig. 3 but for the individual SST patterns in the future climate simulations. (a)-(c) F_C1, (d)-(f) F_C2, and (g)-(i) F_C3.

13a, d, g) for all SST cluster cases. Precipitation in F $\mathrm{C} 1$ tends to increase in the northern part of Japan and the Korean Peninsula in July and August (Figs. 13b, c). Precipitation in July in F_C2 and F_C3 decreases over most parts of the Japanese main islands (Figs. 13e, h). In August, precipitation in F_C2 increases in the northern part of the East China Sea and along the Sea of Japan side of the Japanese archipelago (Fig. 13f). In F_C3, the area of precipitation increase spreads in the Sea of Japan and the western part of Japan (Fig. 13i). Thus, it is found that predictions of future changes to precipitation in July and August depend on the SST patterns.

Sampe and Xie (2010) found that throughout the rainy season, the area with mean ascending motion along the Baiu frontal zone correlates well with the band of warm-air advection. With the progress of the Baiu season in East Asia, the zonal contrast of temperature in the mid-troposphere becomes enhanced; this is because the heated surface of the Asian continent, especially the Tibetan Plateau, and latent heating by monsoonal convection in South Asia, warm the troposphere aloft, leading to a larger difference in mid-troposphere temperature between the Tibetan Pla- 
(a) JRA55

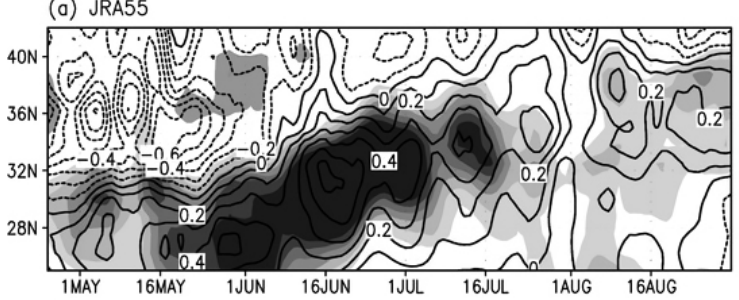

(b) P_OB

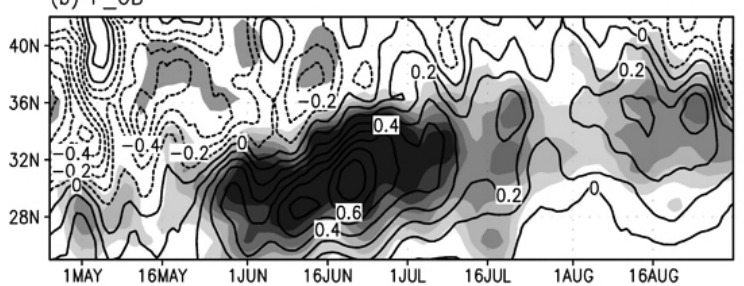

(c) F_CO

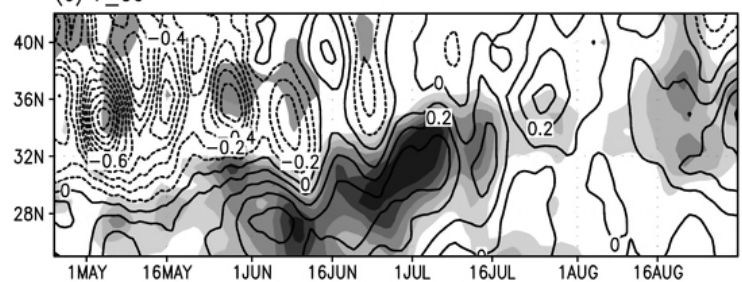

(d) F_C1

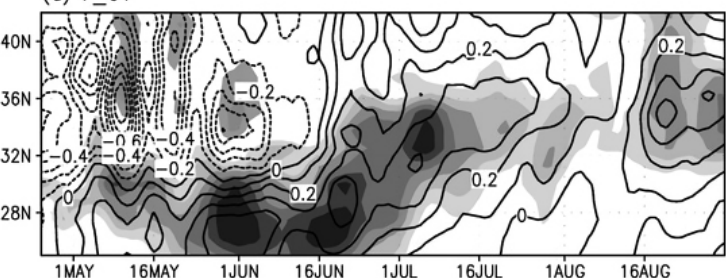

(e) F_C2

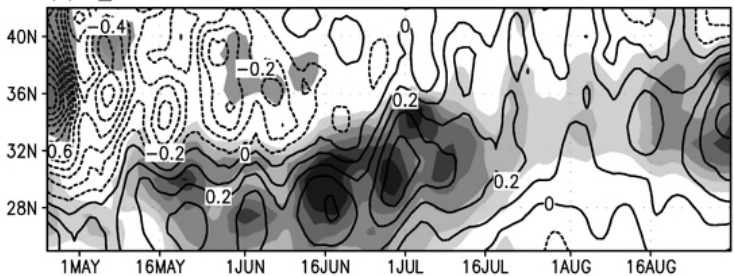

(f) F_C3

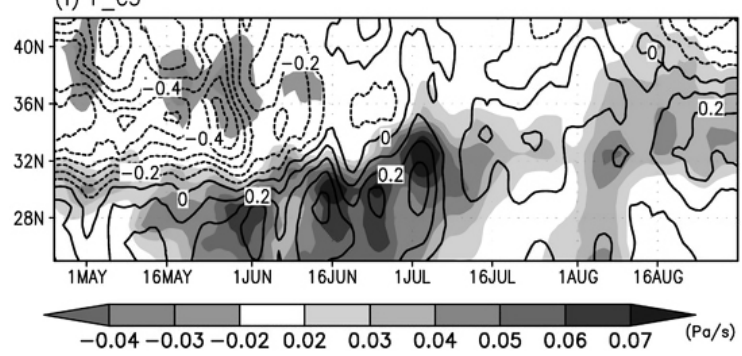

Fig. 14. Time-latitude plot of vertical p-velocity (shading; $\mathrm{Pa} \mathrm{s}{ }^{-1}$ ) and horizontal temperature advection (contours; contour interval $0.1 \mathrm{~K} \mathrm{day}^{-1}$ ) at $500 \mathrm{hPa}$ averaged over the longitudinal range $125-142^{\circ} \mathrm{E}$. This value is derived by twice applying a 5-day running mean for smoothing. Positive (negative) values denote upward (downward) vertical velocity and warm (cold) advection. (a) JRA-55, (b) P OB, (c) F C0, (d) F C1, (e) F C2, and (f) F C3.

teau and the Baiu frontal zone (Kato 1989; Kodama 1993; Ose 1998; Sampe and Xie 2010). The westerlies jet emanating from the eastern flank of the Tibetan Plateau transports the warmer air to the southern part of China and toward the Japanese islands (Sampe and Xie 2010; Okada and Yamazaki 2012). Therefore, warm-air advection is examined here.

Figure 14 shows the relationship between upward vertical pressure velocity $(-\omega)$ and horizontal temperature advection at the $500-\mathrm{hPa}$ level over the Japanese islands. According to Fig. 14, P_OB underestimates upward vertical velocity and warm-air advection at the 500-hPa level compared with JRA-55 during the Baiu season (Figs. 14a, b). However, the positive and negative patterns of seasonal evolution are mostly reproduced. In F_C0, warm-air advection and upward motion are enhanced to the south of $30^{\circ} \mathrm{N}$ until midJune (Fig. 14c). In contrast, cold-air advection and downward motion are significant in the latitudinal band of the western part of the Japanese islands. The enhanced convection moves northward and concentrates in a similar latitudinal band in late June. This northward shift is concurrent with an increase in Baiu rainfall, which peaks in early July in F_C0 (Figs. 4, 14c).

In $\mathrm{F} \_\mathrm{C} 1$, warm-air advection and upward motion 
stay to the south of Japan until mid-June, and an active convective zone undergoes the same northward shift as seen in F_C0 (Fig. 14d). This northward shift in F $\mathrm{C} 0$ terminates in late July. F_C2 and F_C3 also show the stagnation of the enhanced convective zone in the southern part of Japan and cold advection prevails in the north of Japan until late June (Figs. 14d, e). This cold-air advection conducts the stagnation of the Baiu rainband to the south of Japan during June, consistent with the prediction of Kawase et al. (2009). Furthermore, the convective area undergoes a northward shift until the beginning of August in F_C2. In addition, the northward shift in the convective area in F_C3 is slow, and convection becomes weak in late July, in contrast with the other SST patterns. All SST patterns show that the active convective zone stagnates in the southern part of the Japanese islands during June (Figs. 14c-f). However, the seasonal evolution of F_C1 differs from the other two clusters in July and August. F_C1 shows an obvious northward shift after the stagnation of the Baiu frontal zone in June (Fig. 14c). In F_C2 and F_C3, the enhanced convective zone persists from mid-June to early July (Figs. 14e, f). Thereafter, the convective zone in $\mathrm{F} \mathrm{C} 2$ continues until the beginning of August and in $\overline{\mathrm{F}}_{-} \mathrm{C} 3$ becomes weak in mid-July. The precipitation in June in the future climate increases in the southern part of Japan regardless of the SST patterns (Figs. 13a, d, g). In July and August, the seasonal evolution of the convective areas differs slightly between $\mathrm{F}_{-} \mathrm{C} 1, \mathrm{~F}_{-} \mathrm{C} 2$ and F_C3 (Figs. 14c-f).

Regarding these characteristics in July and August, we investigate the future changes of vertically integrated water vapor flux. Figure 15 shows the absolute values of and future changes to the monthly mean moisture flux in July and August between $\mathrm{P} \_\mathrm{OB}$ and each SST simulation. In F C1, the absolute value of the water vapor flux in July indicates an increase of approximately $180 \mathrm{~kg} \mathrm{~m}^{-1}$ day $^{-1}$ in the East China Sea and in the southern part of the Sea of Japan (Fig. 15a). In August, the southwesterly moisture flux becomes weak in these regions, and the areas of high absolute value are concentrated in the Sea of Japan in F_C0 (Fig. 15b). This northward shift of the concentrated area corresponds to the northward shift of the convective area from July to August, as shown in Fig. 14b. This result indicates that $\mathrm{F} \_\mathrm{C} 1$ experiences the termination of the Baiu in late July, as in the present-day climate (Figs. 4, 5). In F_C2 under El Niño-like pattern (Mizuta et al. 2014), the large absolute value of the moisture flux (approximately $120 \mathrm{~kg} \mathrm{~m}^{-1}$ day $^{-1}$ ) spreads in the East China Sea, the southern part of the Sea of Japan, and the Pacific Ocean side of Japan in July (Fig. 15c). This increase of intense moisture flux in July in F_C2 continues till August when the southwesterly flux becomes dominant in the western part of Japan (Fig. 15d). This southwesterly flux deviation transports a sufficient amount of moisture to the Japanese islands and this persistent moisture supply leads to the delay of the Baiu termination in $\mathrm{F}_{-}$ C2. This result is consistent with previous studies (e.g., Kusunoki et al. 2011; Endo et al. 2012; Hirahara et al. 2012). Finally, F_C3 indicates an increase of moisture flux over the East China Sea in July, as do the other two SST patterns (F_C1 and F_C2; Fig. 15e). The westerly moisture flux deviation spreads over the Pacific Ocean off the coast of the Japanese islands. In August, the southwesterly moisture flux becomes dominant in the Japanese islands and the adjacent area, where an increase in absolute value extends to the south of the Japanese main islands (Fig. 15f). In F_C3, which shows strong warming in the WNP (Mizuta et al. 2014), a sufficient amount of moisture is transported to the Pacific coast of the Japanese main islands in the future climate (Fig. 15f). These results indicate that atmospheric conditions in July and August are strongly influenced by SST, whereas those in June are not.

\section{Summary}

Here, we investigated future changes in atmospheric circulation fields during the rainy season in the Japanese islands (referred to as the Baiu) under the RCP 8.5 scenario using 20-km-mesh MRI-AGCM simulations (Mizuta et al. 2012). The future climate was simulated with a control SST and three different SST patterns (Clusters 1, 2, and 3) (Mizuta et al. 2014).

The Baiu frontal zone defined as in the meridional gradient of equivalent potential temperature gradually moves northward during the seasonal evolution of the Baiu in both the present-day and the future climate simulations. Precipitation in the present-day climate (P_OB) reaches a temporal peak during mid-June in the western part of Japan, and this peak is correlated well with observations. However, the temporal peak of precipitation in the future climate using a control SST (F_C0) is delayed by a half month compared with P_OB in the western part of Japan. In June in F_C0, the Baiu frontal zone is projected to stay to the south of Japan, which results in increased precipitation in this region. This result suggests that the Baiu onset is delayed in F_C0. This is attributed to a delay in the reversal of upper-tropospheric meridional thermal gradient between the Asian continent and the north Indian 
(a) F C1 month $=07$

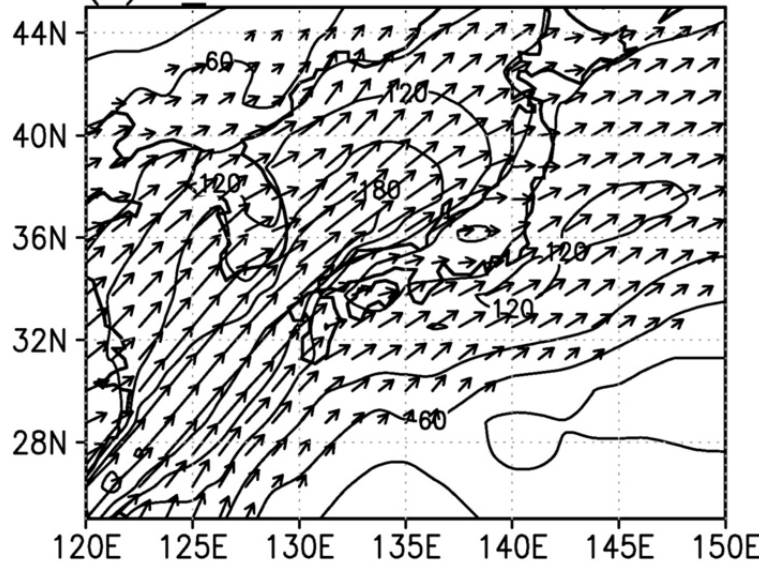

(b) F C1 month $=08$

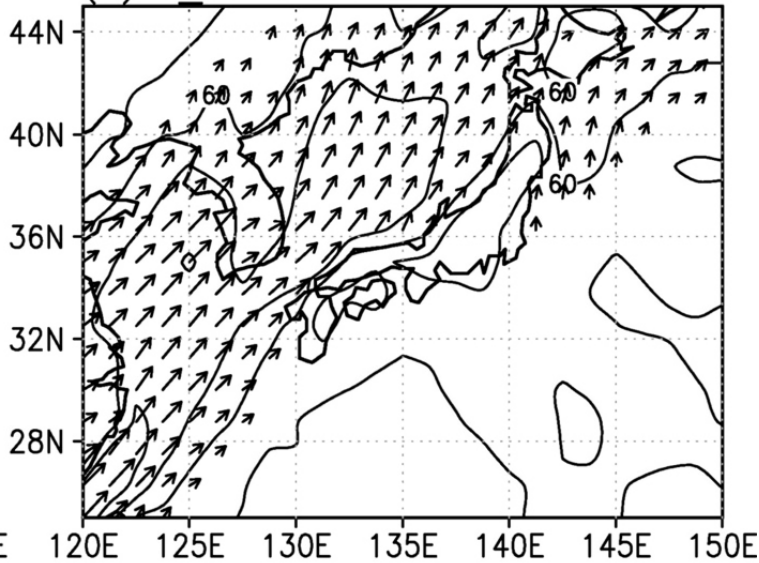

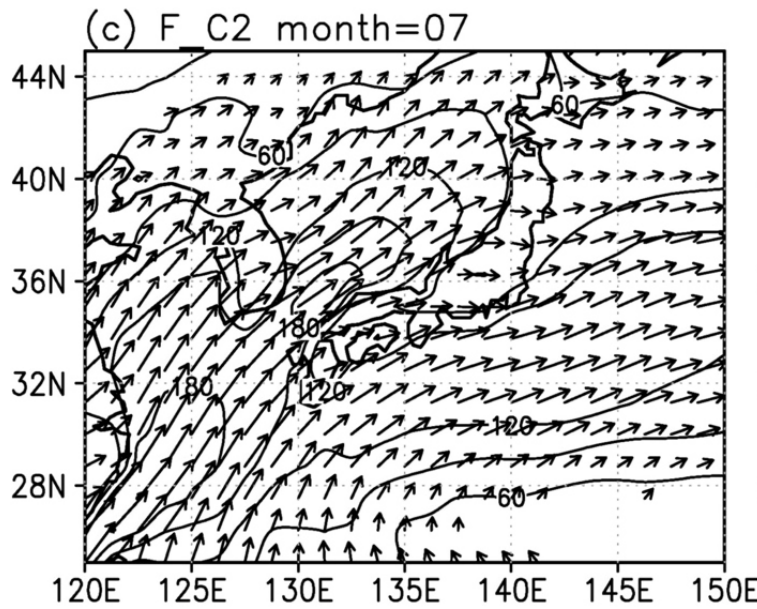

(d) F C2 month $=08$

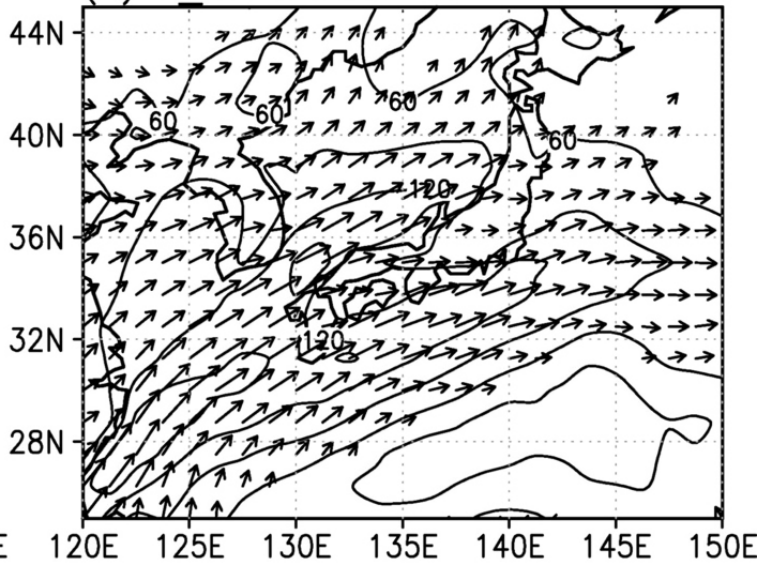

(e) F C3 month $=07$

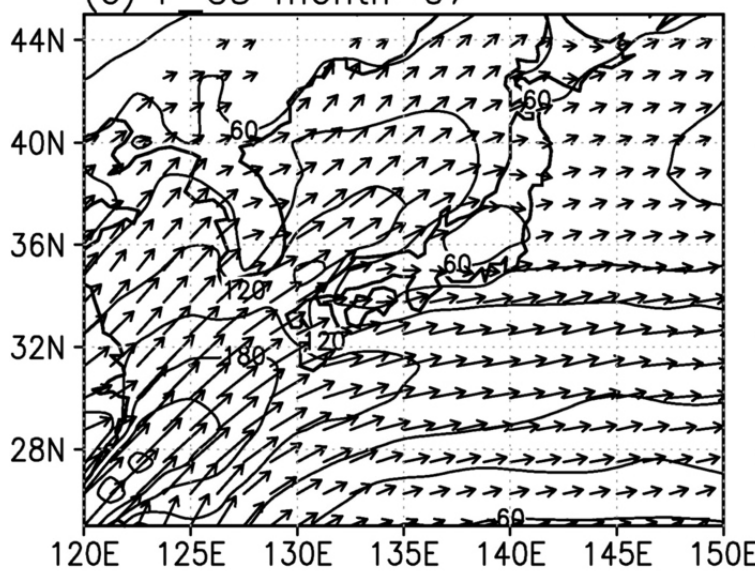

(f) F_C3 month $=08$

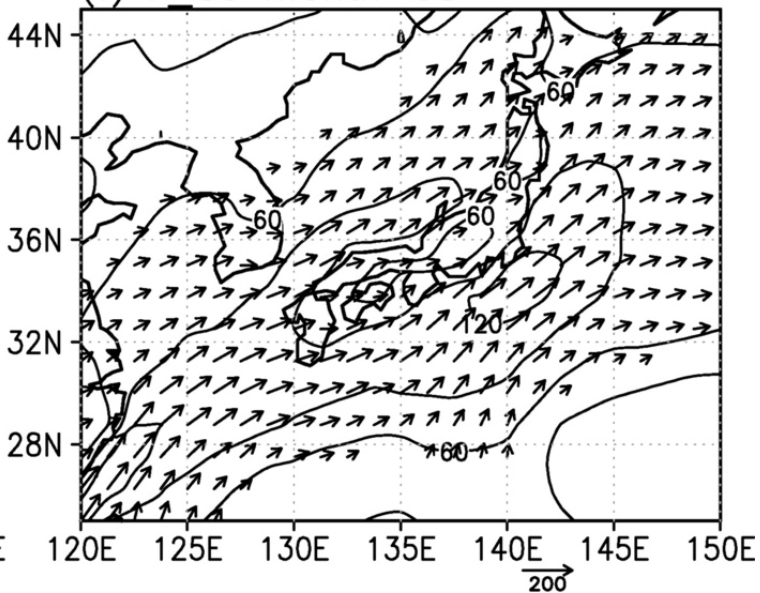

Fig. 15. Future changes (the future climate simulations minus $\mathrm{P}$ OB) of moisture flux (arrows; more than 50 $\mathrm{kg} \mathrm{m}^{-1}$ day $^{-1}$ ) and absolute value of moisture flux (contour) integrated between the 1000-hPa and the 200-hPa level. Future changes indicate differences from P_OB to the future climate simulations. Contour interval is 30 $\mathrm{kg} \mathrm{m}^{-1}$ day $^{-1}$. (a)-(b) F_C1, (c)-(d) F_C2, and (e)-(f) F_C3. Columns indicate (left) July and (right) August. 
Ocean in $\mathrm{F} \mathrm{C} 0$. The future changes in precipitation and atmospheric circulations in June are consistent across all four SST patterns, and therefore, are considered to be robust predictions of future conditions.

We have also examined the response of atmospheric circulation to the difference in SST pattern between July and August. The termination of the Baiu season takes place in late July in F_C0. However, in the other three SST patterns (F_C1, F_C2, and F_C3), atmospheric circulation between July and August differs for each SST pattern. F_C1, with a non-El Niño-like SST pattern, predicts the termination of the Baiu in late July, as seen in P_OB. This termination can be explained by a northward shift of warm-air advection in an upper layer and a southwesterly moisture flux in a lower layer in August. The convective jump (CJ) in the WNP brings the Baiu season to termination in the Japanese main islands. However, in F_C2 and F_C3, the southwesterly flux persists in the Japanese islands until August. In F_C2, with an El Niño-like SST pattern, the absolute value of moisture flux increases significantly in the western part of Japan until August. A sufficient amount of moisture is transported to this region and leads to the delay of the Baiu termination in F_C2, as seen in previous studies (Kitoh et al. 1997; Kusunoki et al. 2011). The SST pattern for F_C3 includes strong warming in the WNP. In F_C3, a sufficient amount of moisture is transported to the Pacific Ocean side of the Japanese islands in July. Although the convergence of moisture flux is smaller than in $\mathrm{F}_{-}$ C2, moisture transport to Pacific Ocean side of the Japanese islands continues until August. In summary, although precipitation in June is consistent across all simulated SST patterns, the atmospheric conditions in July and August are affected by the SST patterns.

These results differ from those of previous studies, primarily in two areas: the precipitation increases to the south of Japan in June, and the termination of the Baiu is not delayed until August. We attribute these differences to differences in the simulation settings employed by previous studies and by the present study, specifically the differences in GCM, emission scenarios, and the distribution of SST. The difference in SST distribution, in particular, leads to a variation in SLP in the WNP, and affects the NPSH around the Japanese islands. We suggest that inconsistencies with previous studies are caused primarily by fluctuations in the NPSH.

\section{Acknowledgments}

This work was conducted under the framework of the "Precise Impact Assessments on Climate Change" of the Program for Risk Information on Climate Change (SOUSEI Program) supported by the Ministry of Education, Culture, Sports, Science, and TechnologyJapan (MEXT). This work was also supported by Kakenhi 16H01846 from JSPS and Integrated Research Program for Advancing Climate Models (TOUGOU Program) of MEXT. The data used in the present study are obtained from the SOUSEI server at University of Tsukuba. Dr. Osamu Arakawa at University at Tsukuba is acknowledged for his effort in maintaining the dataset.

\section{References}

Choi, K.-S., B. Wang, and D. W. Kim, 2012: Changma onset definition in Korea using the available water resources index and its relation to the Antarctic oscillation. Climate Dyn., 38, 547-562.

Endo, H., A. Kitoh, T. Ose, R. Mizuta, and S. Kusunoki, 2012: Future changes and uncertainties in Asian precipitation simulated by multiphysics and multi-sea surface temperature ensemble experiments with highresolution Meteorological Research Institute atmospheric general circulation models (MRI-AGCMs). J. Geophys. Res., 117, D16118, doi:10.1029/2012JD 017874.

Hirahara, S., H. Ohno, Y. Oikawa, and S. Maeda, 2012: Strengthening of the southern side of the jet stream and delayed withdrawal of Baiu season in future climate. J. Meteor. Soc. Japan, 90, 663-671.

Huffman, G. J., R. F. Adler, M. M. Morrissey, D. T. Bolvin, S. Curtis, R. Joyce, B. McGavock, and J. Susskind, 2001: Global precipitation at one-degree daily resolution from multisatellite observations. J. Hydrometeor., 2, 36-50.

Inoue, T., and H. Ueda, 2011: Delay of the first transition of Asian summer monsoon under global warming condition. SOLA, 7, 81-84.

Inoue, T., and H. Ueda, 2012: Delay of the Baiu withdrawal in Japan under global warming condition with relevance to warming patterns of SST. J. Meteor. Soc. Japan, 90, 855-868.

IPCC, 2007: Climate Change, 2007: The Physical Science Basis. Contribution of Working Group I to the Fourth Assessment Report of the Intergovernmental Panel on Climate Change, Solomon, S., D. Qin, M. Manning, Z. Chen, M. Marquis, K. B. Averyt, M. Tignor, and H. L. Miller (eds.), Cambridge University Press, Cambridge, UK, and New York, USA, 996 pp.

IPCC, 2013: Climate Change 2013: The Physical Science Basis. Contribution of Working Group I to the Fifth Assessment Report of the Intergovernmental Panel on Climate Change. Stocker, T. F., D. Qin, G. K. Plattner, M. Tignor, S. K. Allen, J. Boschung, A. Nauels, Y. Xia, V. Bex, and P. M. Midgley (eds.), Cambridge University Press, Cambridge, UK, and New York, 
USA, $1535 \mathrm{pp}$.

Kanada, S., M. Nakano, and T. Kato, 2012: Projections of future changes in precipitation and the vertical structure of the frontal zone during the Baiu season in the vicinity of Japan using a 5-km-mesh regional climate model. J. Meteor. Soc. Japan, 90A, 65-86.

Kato, K., 1985: On the abrupt change in the structure of the Baiu front over the China continent in late May of 1979. J. Meteor. Soc. Japan, 63, 20-36.

Kato, K., 1989: Seasonal transition of the lower-level circulation systems around the Baiu front in China in 1979 and its relation to the Northern Summer Monsoon. $J$. Meteor. Soc. Japan, 67, 249-265.

Kawase, H., T. Yoshikane, M. Hara, F. Kimura, T. Yasunari, B. Ailikun, H. Ueda, and T. Inoue, 2009: Intermodel variability of future changes in the Baiu rainband estimated by the psedo global warming downscaling method. J. Geophys. Res., 114, D24110, doi:10.1029/ 2009JD011803.

Kitoh, A., and T. Uchiyama, 2006: Changes in onset and withdrawal of the East Asian summer rainy season by multi-model global warming experiments. J. Meteor. Soc. Japan, 84, 247-258.

Kitoh, A., S. Yukimoto, A. Noda, and T. Motoi, 1997: Simulated changes in the Asian summer monsoon at times of increased atmospheric $\mathrm{CO}_{2}$. J. Meteor. Soc. Japan, 75, 1019-1031.

Kobayashi, S., Y. Ota, Y. Harada, A. Ebita, M. Moriya, H. Onoda, K. Onogi, H. Kamahori, C. Kobayashi, H. Endo, K. Miyaoka, and K. Takahashi, 2015: The JRA-55 Reanalysis: General specifications and basic characteristics. J. Meteor. Soc. Japan, 93, 5-48.

Kodama, Y.-M., 1993: Large-scale common features of subtropical convergence zones (the Baiu frontal zone, the SPCZ, and the SACZ). Part II: Conditions of the circulations for generating the STCZs. J. Meteor. Soc. Japan, 71, 581-610.

Kusunoki, S., 2016: Is the global atmospheric model MRIAGCM3.2 better than the CMIP5 atmospheric models in simulating precipitation over East Asia? Climate Dyn., doi:10.1007/s00382-016-3335-9.

Kusunoki, S., J. Yoshimura, H. Yoshimura, A. Noda, K. Oouchi, and R. Mizuta, 2006: Change of Baiu rain band in global warming projection by an atmospheric general circulation model with a $20-\mathrm{km}$ grid size. $J$. Meteor. Soc. Japan, 84, 581-611.

Kusunoki, S., R. Mizuta, and M. Matsueda, 2011: Future changes in the East Asian rain band projected by global atmospheric models with $20-\mathrm{km}$ and $60-\mathrm{km}$ grid size. Climate Dyn., 37, 2481-2493.

Lau, K.-M., H.-T. Wu, and S. Yang, 1998: Hydrologic processes associated with the first transition of the Asian summer monsoon: A pilot satellite study. Bull. Amer. Meteor. Soc., 79, 1871-1882.

Li, C., and M. Yanai, 1996: The onset and interannual variability of the Asia summer monsoon in relation to land-sea thermal contrast. J. Climate, 9, 358-375.

Matsumoto, J., 1997: Seasonal transition of summer rainy season over Indochina and adjacent monsoon region. Adv. Atmos. Sci., 14, 231-245.

Matsumoto, S., K. Ninomiya, and S. Yoshizumi, 1971: Characteristic features of "Baiu" front associated with heavy rainfall. J. Meteor. Soc. Japan, 49, 267-281.

Meehl, G. A., C. Covey, K. E. Taylor, T. Delworth, R. J. Stouffer, M. Latif, B. McAvaney, and J. F. B. Mitchell, 2007: The WXRP CMIP3 multi-model dataset: A new era in climate change research. Bull. Amer. Meteor. Soc., 88, 1383-1394.

Mizuta, R., H. Yoshimura, H. Murakami, M. Matsueda, H. Endo, T. Ose, K. Kamiguchi, M. Hosaka, M. Sugi, S. Yukimoto, S. Kusunoki, and A. Kitoh, 2012: Climate simulations using MRI-AGCM3.2 with 20-km grid. $J$. Meteor. Soc. Japan, 90A, 233-258.

Mizuta, R., O. Arakawa, T. Ose, S. Kusunoki, H. Endo, and A. Kitoh, 2014: Classification of CMIP5 future change climate responses by the tropical sea surface temperature changes. SOLA, 10, 167-171.

Ninomiya, K., 1984: Characteristics of Baiu front as a predominant subtropical front in the summer Northern Hemisphere. J. Meteor. Soc. Japan, 62, 880-894.

Ninomiya, K., and T. Akiyama, 1992: Multi-scale features of Baiu, the summer monsoon over Japan and East Asia. J. Meteor. Soc. Japan, 70, 467-495.

Okada, Y., and K. Yamazaki, 2012: Climatological evolution of the Okinawa Baiu and differences in large-scale features during May and June. J. Climate, 25, 62876303.

Onogi, K., J. Tsutsui, H. Koide, M. Sakamoto, S. Kobayashi, H. Hatsushika, T. Matsumoto, N. Yamazaki, H. Kamahori, K. Takahashi, S. Kadokura, K. Wada, K. Kato, R. Oyama, T. Ose, N. Mannoji, and R. Taira, 2007: The JRA-25 Reanalysis. J. Meteor. Soc. Japan, 85, 369432.

Ose, T., 1998: Seasonal change of Asian summer monsoon circulation and its heat source. J. Meteor. Soc. Japan, 76, 1045-1063.

Sampe, T., and S.-P. Xie, 2010: Large-scale dynamics of the Meiyu-Baiu rainband: Environmental forcing by the westerly jet. J. Climate, 23, 113-134.

Takahashi, K., N. Yamazaki, and H. Kamahori, 2006: Trends of heavy precipitation events in global observation and reanalysis datasets. SOLA, 2, 96-99.

Tanaka, H., 2007: The Meteorology of Westerlies. Seizando, 174 pp (in Japanese).

Tanaka, M., 1992: Intraseasonal oscillation and the onset and retreat dates of the summer monsoon over East, Southeast Asia and the Western Pacific Region using GMS high cloud amount data. J. Meteor. Soc. Japan, 70, 613-629.

Uchiyama, T., and A. Kitoh, 2004: Changes in BaiuChangma-Meiyu rain by global warming in MRICGCM. Proceedings of the International Conference 
on High-Impact Weather and Climate, Seoul, Korea, 218-221.

Ueda, H., and T. Yasunari, 1998: Role of warming over the Tibetan Plateau in early onset of the summer monsoon over the Bay of Bengal and the South China Sea. J. Meteor. Soc. Japan, 76, 1-12.

Ueda, H., T. Yasunari, and R. Kawamura, 1995: Abrupt seasonal change of large-scale convective activity over the western Pacific in the northern summer. J. Meteor. Soc. Japan, 73, 795-809.

Ueda, H., A. Iwai, K. Kuwako, and M. E. Hori, 2006: Impact of anthropogenic forcing on the Asian summer monsoon as simulated by 8 GCMs. Geophys. Res. Lett., 33, L0673, doi:10.1029/2005GL025336.

Ueda, H., M. Ohba, and S.-P. Xie, 2009: Impact factors for the development of the Asian-northwest Pacific summer monsoon. J. Climate, 22, 649-669.

Wang, B., and LinHo, 2002: Rainy season of the AsianPacific summer monsoon. J. Climate, 15, 386-396.
Watarai, Y., and H. L. Tanaka, 2007: Characteristic of the JRA-25 dataset from the viewpoint of global energetics. SOLA, 3, 9-12.

Yamaguchi, K., and A. Noda, 2006: Global warming patterns over the North Pacific: ENSO versus AO. J. Meteor. Soc. Japan, 84, 221-241.

Yatagai, A., K. Kamiguchi, O. Arakawa, A. Hamada, N. Yasutomi, and A. Kitoh, 2012: APHRODITE: Constructing a long-term daily gridded precipitation dataset for Asia based on a dense network of rain gauges. Bull. Amer. Meteor. Soc., 93, 1401-1415.

Yoshimura, H., R. Mizuta, and H. Murakami, 2015: A spectral cumulus parameterization scheme interpolating between two convective updrafts with semi-Lagrangian calculation of transport by compensatory subsidence. Mon. Wea. Rev., 143, 597-621. 